\title{
Chemical and microphysical properties of the aerosol during foggy and nonfoggy episodes: a relationship between organic and inorganic content of the aerosol
}

\section{S. Kaul, T. Gupta, and S. N. Tripathi}

Department of Civil Engineering, Indian Institute of Technology, Kanpur, India

Received: 12 May 2012 - Accepted: 29 May 2012 - Published: 7 June 2012

Correspondence to: T. Gupta (tarun@iitk.ac.in), S. N. Tripathi (snt@iitk.ac.in)

Published by Copernicus Publications on behalf of the European Geosciences Union.
Relationship between organic and inorganic content of the aerosol

D. S. Kaul et al.

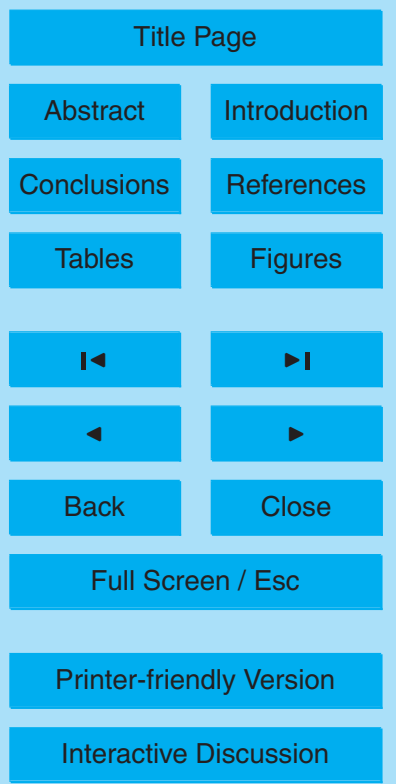




\section{Abstract}

An extensive field measurement during winter was carried out at a site located in the Indo-Gangetic Plain (IGP) which gets heavily influenced by the fog during winter almost every year. The chemical and microphysical properties of the aerosols during foggy and

5 nonfoggy episodes and chemical composition of the fogwater are presented. Positive matrix factorization (PMF) as a tool for the source apportionment was employed to understand the sources of pollution. Four major sources viz. biomass burning, refractory, secondary and mineral dust were identified. Aerosols properties during foggy episodes were heavily influenced by almost all the sources and they caused considerable loading of almost all the organic and inorganic species during the period. The biomass generated aerosols were removed from the atmosphere by scavenging during foggy episodes. The wet removal of almost all the species by the fog droplets was observed. The $\mathrm{K}^{+}$, water soluble organic carbon (WSOC), water soluble inorganic carbon (WSIC) and $\mathrm{NO}_{3}^{-}$were most heavily scavenged among the species and their concentrations consequently became lower than the nonfoggy episode concentrations. The production of secondary inorganic aerosol, mainly sulfate and ammonium, during foggy episodes was considerably higher than nitrate which was rather heavily scavenged and removed by the fog droplets. The fogwater analysis showed that dissolved inorganic species play a vital role in processing of organic carbon such as the formation of organo-sulfate and organo-nitrate inside the fog droplets. The formation of organo-sulfate and organonitrate in aerosol and the influence of acidity on the secondary organic aerosol (SOA) formation were rather found to be negligible. The study average inorganic component of the aerosol was considerably higher than the carbonaceous component during both foggy and nonfoggy episode. The secondary production of the aerosol changed the microphysical properties of aerosol which was reflected by increase in the modal diameter of the size distribution during foggy episodes and growth in the diameter of the particles upon the fog evaporation.

\section{Relationship between organic and inorganic content of the aerosol}

D. S. Kaul et al.

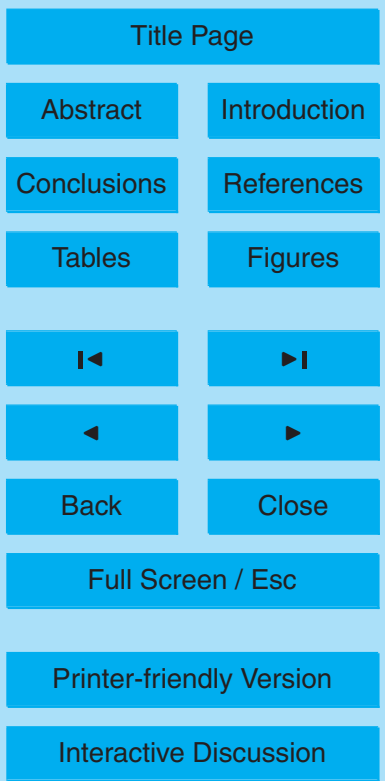




\section{Introduction}

Indo-Gangetic plain (IGP) region is affected by the fog almost every winter. The fog episodes have been extensively studied as exemplified by the numerous articles due to its effect on the visibility, public health and global climate (Charlson et al., 1992;

5 Hou et al., 2012; Kaul et al., 2011; Lee and Sequeira, 2002; Sun et al., 2006; Wang et al., 2011b). The hygroscopic aerosols in the atmosphere act as cloud condensation nuclei for fog formation upon which water vapor condenses on. Fog plays important role in chemical transformation of gaseous species by scavenging and subsequent oxidation of dissolved gaseous species. Sulfate is produced when the precursor gases such as 10 the dissolved $\mathrm{SO}_{2}$ in the fog droplets is oxidized by the dissolved oxidants. The rate of sulfate production depends on the concentration of $\mathrm{SO}_{2}$ and the concentration of dissolved oxidants. Nitrate is produced by the heterogeneous reaction of $\mathrm{N}_{2} \mathrm{O}_{5}$ on the fog droplets (Lillis et al., 1999). The aqueous transformation of gaseous species produces sulfate, nitrate and ammonium which accumulate on interstitial particles thus producing higher concentration of these species in the aerosols during fog and haze episodes (Cass, 1979; Sun et al., 2006; Sievering et al., 1992). Black carbon (BC) inside the fog droplets also interacts with sulfate and attachment of the sulfate to $B C$ is another reason for higher sulfate concentration in the aerosols during foggy episodes. BC concentration was also observed to be higher during fog episodes (Orrling et al., 2012; Ulevicius et al., 1994).

Falling droplets remove the scavenged gases from the atmosphere. The interstitial aerosols in the fog droplets as well as other aerosols colliding with fog droplets are removed by the falling droplets (Herckes et al., 2007; Wang et al., 2011b). The field experimental observations have documented that scavenging of gases and particles are droplet size dependent (Krämer et al., 2000; Moore et al., 2004). Scavenging can be identified by analyzing the constituents of the fogwater such as organic compounds like carboxylic acids and inorganic compounds like $\mathrm{SO}_{4}^{2-}, \mathrm{NO}_{3}^{-}$and $\mathrm{NH}_{4}^{+}$and organosulfate and organo-nitrate (Herckes et al., 2006). The wet scavenging of $\mathrm{NO}_{3}^{-}$and $\mathrm{Cl}^{-}$

\section{ACPD}

$12,14483-14524,2012$

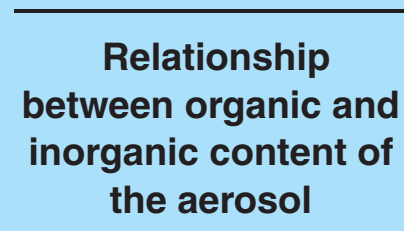

D. S. Kaul et al.

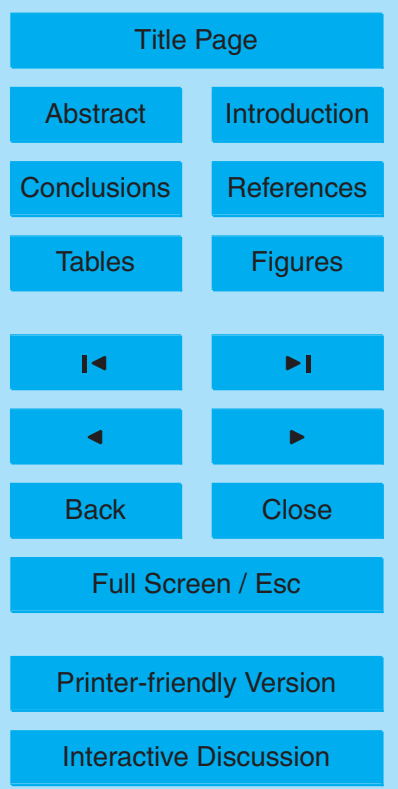


were reported to be higher than that of $\mathrm{SO}_{4}^{2-}$ and $\mathrm{NH}_{4}^{+}$due to the solubility difference of these species inside the fog droplets. The species constituting the coarse aerosols were found to have negligible difference during foggy and nonfoggy episodes (Aikawa et al., 2007; Zhang and Tie, 2011). Investigators (Lillis et al., 1999) have reported 5 that $\mathrm{SO}_{4}^{2-}, \mathrm{NO}_{3}^{-}$and $\mathrm{NH}_{4}^{+}$are removed by the fog droplets through the wet deposition process.

Concentration of $\mathrm{K}^{+}$in the aerosols have been used as tracer for biomass burning in a few studies (Duan et al., 2004) and a few investigators (Zhang et al., 2010) have shown that this tracer during winter is as good as levoglucosan due to negligible in10 fluence by other sources on $\mathrm{K}^{+}$concentrations. Thus, presence of $\mathrm{K}^{+}$can be used to evaluate biomass burning and its effect on chemical and microphysical properties of aerosols. The presence of ionic species such as ammonia, nitrate, and sulfate in the aerosol can change the chemical properties of the aerosols and may also influence cloud formation, visibility, acidification of the aerosols and climate change (Charlson 5 et al., 1992; Hou et al., 2012; Lee and Sequeira, 2002; Sun et al., 2006; Wang et al., 2005). Atmospheric aerosol also carries toxic organic compounds which are detrimental to the human health and ecosystems (Pope et al., 2002; Sunyer, 2001).

Inorganic compounds also help in conversion of volatile organic compound (VOC) to organic aerosols. The organic aerosols which are directly emitted are referred to as 20 primary organic aerosol (POA). Globally, $20 \%$ of the total organic aerosol mass is POA (Kanakidou et al., 2005; Spracklen et al., 2011). The aerosol produced by chemical photo-oxidation in the atmosphere is referred to as secondary organic aerosols (SOA). SOA is produced by both gas to particle partitioning mechanism (Bowman et al., 1997; Odum et al., 1997) and aqueous phase mechanism (Blando and Turpin, 2000; Huang 25 et al., 2011; Ravishankara, 1997; Ervens et al., 2011; Volkamer et al., 2007; Wang et al., 2012). In the gas to particle partitioning mechanism, VOCs directly emitted from the anthropogenic and natural sources are photo-oxidized by oxidant such as $\mathrm{O}_{3}$ and $\mathrm{OH}$ radical and semi volatile organic compounds are produced which then condense over the pre-existing aerosols or may form new particles. In the aqueous mechanism

\section{ACPD}

$12,14483-14524,2012$

\section{Relationship \\ between organic and inorganic content of the aerosol}

D. S. Kaul et al.

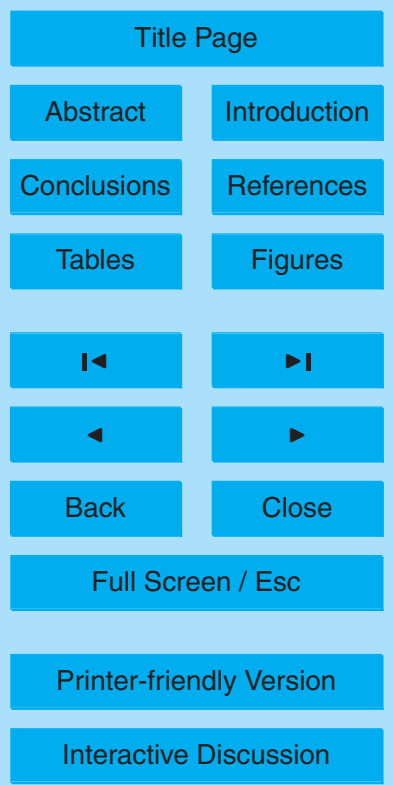


such as in the fogs and clouds, VOCs are scavenged and dissolved into the droplets. Subsequent reaction and oxidation of dissolved VOCs by dissolved oxidants inside the fog droplets produces more oxygenated organic compounds compared to those produced from gas to particles mechanism (Aiken et al., 2008; $\mathrm{Ng}$ et al., 2011). As 5 these fog droplets evaporate, the oxygenated compounds are left behind and condense over the interstitial particles. Globally, water content of the aerosol exceeds the dry aerosol mass composed of ammonium, sulfate and nitrate by a factor of 2-3 which indicates that accessibility of water soluble species to an aqueous phase will be larger than to solid phase (Meng et al., 1995; Wang et al., 2008). Freshly emitted hydrophobic 10 aerosols which can contain very little water are converted into hydrophilic aerosol which can retain more water, through photo-oxidation aging in the atmosphere (Ervens and Volkamer, 2010; Riemer et al., 2010).

In addition, the chemistry of aerosol can affect the conversion rate of VOCs to organic phase. For example, SOA production is enhanced during acidic condition of the aerosols due to the oligomerization and formation of higher molecular organic compounds which partitions into the particle phase. However, the influence of acidity on the enhanced SOA yield is mostly limited to the chamber studies (Offenberg et al., 2009). Most ambient studies have shown negligible effect of acidity on SOA yield (Tanner et al., 2009) with only a few exceptions (Rengarajan et al., 2011). Organic compounds produced from the oligomerization are composed of heteroatom molecules (e.g. sulfur and nitrogen) and may constitute the considerable portion ( 4-80\% of particulate mass) of organic aerosols (Blando et al., 1998; Fuzzi et al., 2001; Romero and Oehme, 2005; Stone et al., 2009, 2012; Surratt et al., 2006). Thus, inorganic species play a significant role in conversion of oxygenated compounds to the organic phase.

The production of SOA will be reflected by changes in the microphysical properties of the aerosols. Ambient aerosols show two distinct modes; one is $<0.2 \mu \mathrm{m}$ which is referred to as the condensation mode and other in $0.5-1.0 \mu \mathrm{m}$ which is referred to as the larger (droplet) mode. Droplet mode evolves from the condensation phase mode by volume phase reaction in the clouds and wet aerosols such as the aqueous production

\section{Relationship between organic and inorganic content of the aerosol}

D. S. Kaul et al.

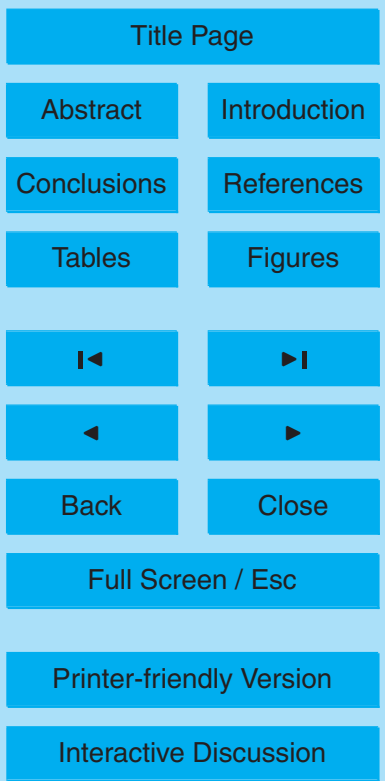

14487 
of sulfate (Hering and Friedlander, 1982; John et al., 1990; Meng et al., 1995). Association of organic compounds with inorganic compounds such as organo-sulfate and organo-nitrate has been previously observed in the wet aerosols (Blando et al., 1998; Pickle et al., 1990; Galloway et al., 2009; Kua et al., 2011; Noziere et al., 2008; Perri et 5 al., 2010; Shapiro et al., 2009). Aqueous production of SOA is reflected by the changes in the organic carbon of the aerosols, aerosol number, and surface and volume concentrations. Changes in the organic carbon will be due to partioning or condensation of the semi-VOCs over preexisting aerosols. Volume concentration increases due to the growth of the aerosols which could be due to condensation of semi-VOCs on the ex10 isting aerosols and aqueous chemistry followed by the growth of the aerosols. Number may increase due to new particle formation from the oxidation of VOCs. The growth of the particle and change in the number size distribution due to aqueous SOA formation has also been previously documented (Berkowitz et al., 2011; Jung et al., 2011; Ulevicius et al., 1994).

15 The direct estimate of the SOA could not be carried out due to the unknown reaction pathways and numerous organic compounds involved in its formation. Thus, several indirect methods have come up to estimate SOA and one among them is the EC tracer method (Castro et al., 1999; Turpin and Huntzicker, 1995). In our previous study (Kaul et al., 2011), we had applied EC tracer method to study SOA formation during foggy and nonfoggy episode. It was demonstrated that the SOA production was higher during foggy episode and shows diurnal variation during both foggy and nonfoggy episodes. The production of SOA deduced from the OC/EC ratio as fog was evaporating was highest during afternoon while lowest during morning and evening hours during both foggy and nonfoggy episode (Kaul et al., 2011). The forenoon to afternoon increase in production of SOA was due to the photo-oxidation reaction. Higher value of SOA during foggy episode was due to the aqueous phase production of SOA (Kaul et al., 2011). Thus, chemical and microphysical properties of aerosol during foggy episode and from the forenoon to afternoon during foggy episodes of evaporating fog will inflict some signature of the properties of SOA.

\section{Relationship between organic and inorganic content of the aerosol}

D. S. Kaul et al.

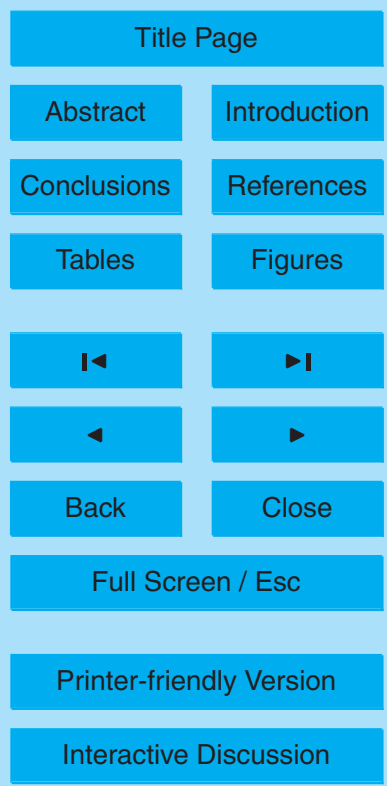


Numerous research work done on chamber studies have shown that SOA is scattering in nature and its formation will lead to increase in size of the aerosols. Some investigators have also evaluated the effect of inorganic species on SOA formation such as the oligomerization and role of $\mathrm{SO}_{4}^{2-}$ on $\mathrm{SOA}$ formation but detailed relationship 5 between organic aerosols and inorganic species such as formation of organo-sulfate and organo-nitrate and effect of aerosol acidity of organic aerosol formation is unidentified as discussed above. Most investigations of microphysical and chemical properties of SOA and its relationship with chemistry and microphysics are limited to chamber studies due to contamination from other types of aerosol in the ambient studies. The 10 ambient measurements acquire greater significance to determine the actual properties of and mechanism leading to the SOA formation and also to validate the chamber studies. The main objective of this paper is to capture the microphysical and chemical properties of the aerosols and relate them with carbonaceous aerosols. The more reliable knowledge of aerosol properties during foggy and nonfoggy conditions will lead to better understanding of mitigation of fog related problems such as health hazard, delay in rail and air transport and traffic related accidents which are caused by the reduced visibility due to fog formation. The detailed organic and inorganic chemistry will help in modeling and predicting fog formation effectively.

\section{Experimental section}

20 Sampling was carried out at Indian Institute of Technology, Kanpur $\left(26.5^{\circ} \mathrm{N}, 80.3^{\circ} \mathrm{E}\right)$ which is located in the most populated ( 2.6 million) and one of the most polluted regions of Indo-Gangetic Plain (IGP). Details of sampling is included in our previous work (Kaul et al., 2011), only brief information regarding sampling will be presented here. The major emission sources of the region include industries, domestic fuel combustion and vehicle transport, biomass burning (Behera and Sharma, 2010; Mehta et al., 2009). Time integrated six $\mathrm{PM}_{1}$ samples on $47 \mathrm{~mm}$ quartz filters (Whatman, QMA) were collected every $24 \mathrm{~h}$ from 16 January 2010 to 20 February 2010 using a custom designed

\section{ACPD}

$12,14483-14524,2012$

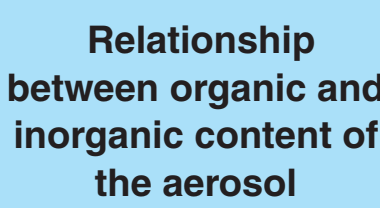

D. S. Kaul et al.

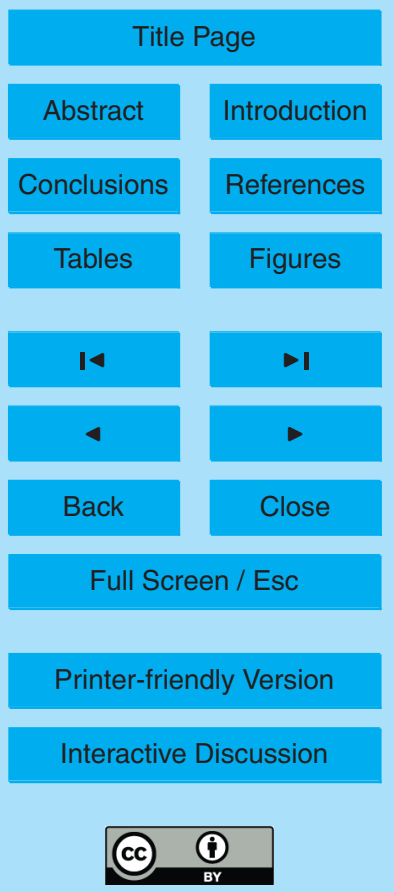


inertial based sampler (Gupta et al., 2010, 2011; Chakraborty and Gupta, 2010). The sampler operates at $10 \mathrm{I} \mathrm{min}^{-1}$ flow rate and has a cut off size $\left(d_{50}\right)$ of $1 \mu \mathrm{m}$. The sampling schedule during the study period were: one from 07:30 a.m. to 10:30 a.m., one every $2.5 \mathrm{~h}$ from 11:00 a.m. to 11:30 p.m. with a $30 \mathrm{~min}$ gap between successive sam5 ples (for sample change out) and one night time sample from 12:00 a.m. to 07:00 a.m. All the filters were pre- and post-weighed using an analytical microbalance (Mettler, MT-5). All the filters were heated for $6-8 \mathrm{~h}$ at $\sim 700^{\circ} \mathrm{C}$ prior to sampling to remove the background adsorbed organics on the filters. The blank concentrations were deducted from the measured concentrations. Total number of samples thus collected was 180 , 10 of which 54 samples were collected during foggy episodes. All the filters thus collected were stored in a freezer until the analysis. Several punches (each of diameter: $2.11 \mathrm{~cm}^{2}$ ) from filters were cut for different types of analysis. Few punches of each filter were liquid (milli-Q water) extracted by ultrasonication (Ultrasonic Cleaner, 2k909008). The filtrates were analyzed for the cations $\left(\mathrm{Ca}^{2+}, \mathrm{Mg}^{2+}, \mathrm{Na}^{+}, \mathrm{NH}_{4}^{+}, \mathrm{K}^{+}\right)$and anions $\left(\mathrm{F}^{-}\right.$, ${ }_{15} \mathrm{Cl}^{-}, \mathrm{NO}_{3}^{-}, \mathrm{SO}_{4}^{2-}$ ) by an lon Chromatograph (Metrohm, 882 Compact IC plus).

Fogwater samples were collected using a three stage Caltech Active Strand Cloudwater Collector (3-stage-sf-CASCC) built at Colorado State University following earlier 2-stage-sf-CASCC (Demoz et al., 1996; Raja et al., 2008; Kaul et al., 2011). The 3stage-sf-CASCC has cut off size of 4,16 and $22 \mu \mathrm{m}$ fog droplets. Sampler was cleaned 20 and blanks were collected prior to sampling. Fogwater samples thus collected were stored in a freezer until the analysis. Fogwater samples were filtered by Millipore filters of $0.22 \mu \mathrm{m}$ pore size and were analyzed for the ionic species using an ion chromatograph. TOC analysis on all filters samples and collected fogwater was carried out by a TOC analyzer (Model No: TOC-V CPN, Shimadzu Corporation). The precise duration of the fog episodes and planetary boundary layer (PBL) was obtained by a Micro-pulse Lidar (Model No: 633SP, Ekto Manufacturing Corporation), a part of NASA (National Aeronautics and Space Administration) MPLnet which provides vertical structure of the atmosphere every minute. A typical fog event of 16 January 2010 at 05:15 a.m. UTC obtained from the MODIS and the MPL ( $L 1.5 \mathrm{~b}$ data) can be seen at

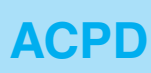

$12,14483-14524,2012$

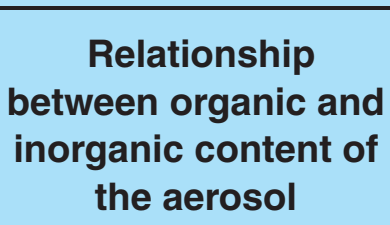

D. S. Kaul et al.

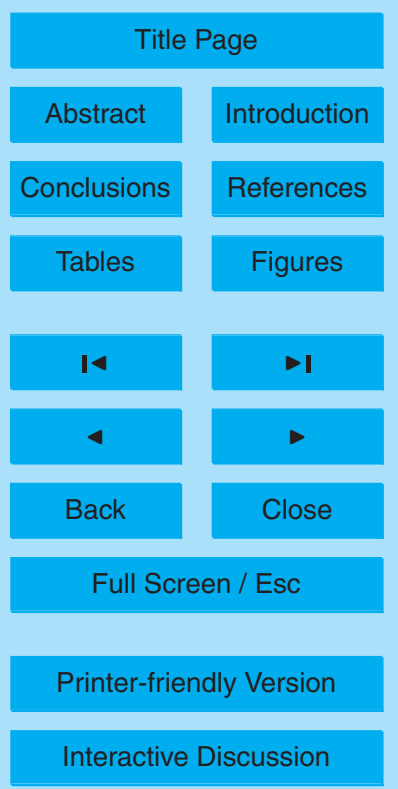


http://aeronet.gsfc.nasa.gov/. More details on characterizing the foggy and nonfoggy sampling duration are included elsewhere (Kaul et al., 2011).

A Scanning Mobility Particle Sizer (TSI Inc., Model-3936) was continuously run (resolution $=1.5 \mathrm{~min}$ ) to measure aerosol size distribution in the size range of $14.6-685.4 \mathrm{~nm}$ 5 mobility diameter. It operates at sample flow rate of $0.31 \mathrm{~min}^{-1}$ and at sheath flow rate of $31 \mathrm{~min}^{-1}$. The particles are classified based on their mobility diameter using an electrostatic classifier (TSI Inc., Model-3080) and a differential mobility analyzer (TSI Inc., Model-3081) and are counted by a condensation nuclei counter (TSI Inc., Model-3775).

One punch of each filters was used for measuring organic carbon $(\mathrm{OC})$ and elemen10 tal carbon (EC) of the aerosols by a EC-OC analyzer (Model No-4F, Sunset Laboratory Inc.) following NIOSH 5040 method (Birch and Cary, 1996; Eller and Cassinelli, 1996). Filter blanks were subtracted from the measured values. Primary organic aerosol (POA) and secondary organic aerosol (SOA) were estimated using EC-tracer method which requires $\mathrm{OC}$ and $\mathrm{EC}$ measurements. More details regarding the carbonaceous 15 measurement are documented in our previous study (Kaul et al., 2011).

Meteorological data such as temperature $(T)$ and relative humidity $(\mathrm{RH})$ were measured by a Vaisala Humidcap (HMT 337, Serial No: B4050039). The temporal resolution of temperature and relative humidity measurement was $1 \mathrm{~s}$. Other atmospheric conditions such as wind speed and wind direction (temporal resolution $=30 \mathrm{~min}$ ) were measured using automatic weather station, details of wind speed and direction are included in our previous article (Kaul et al., 2011). A pyranometer (Model No: CM2, KIPP \& ZONEN DELFT/HOLLAND), which is a part of AERONET (Aerosol Robotic Network), was used for incoming solar radiation $(F)$ measurement at 2 min temporal resolution. Trace gas species $\left(\mathrm{SO}_{2}, \mathrm{O}_{3}\right.$ and $\left.\mathrm{CO}\right)$ were measured at $15 \mathrm{~min}$ temporal resolution using a $\mathrm{SO}_{2}$ gas analyzer (Model No: 43i, Thermo Scientific), an $\mathrm{O}_{3}$ gas analyzer (Model No: 49i, Thermo Scientific) and a CO gas analyzer (Model No: 48i, Thermo Scientific). Trace gas measurement, meteorological and microphysical data were averaged over $\mathrm{PM}_{1}$ sampling durations and averaged values are reported the middle of the sampling duration in all the time series plots and Fig. 8b.

\section{ACPD}

$12,14483-14524,2012$

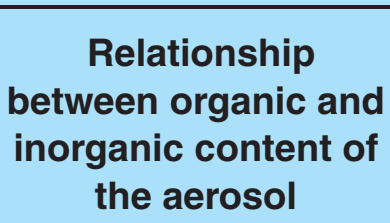

D. S. Kaul et al.

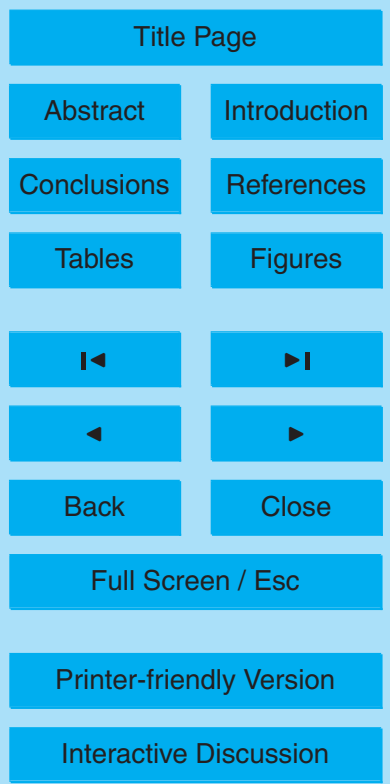




\section{Results and discussions}

\subsection{Atmospheric conditions and trace gas}

The study average diurnal variation of atmospheric conditions and trace gas measurements are included in our previous article (Kaul et al., 2011). The foggy episode study 5 average temperature $(T)$ and solar flux $(F)$ was lesser than nonfoggy episode and relative humidity $(\mathrm{RH})$ was higher during foggy episode. The study average $\mathrm{O}_{3}$ and $\mathrm{SO}_{2}$ concentrations were lower and $\mathrm{CO}$ concentration was higher during foggy episode. These conditions indicate reduced photo-oxidation reaction during foggy episode. More details are included in (Kaul et al., 2011), only time series of the meteorological and trace gas measurement will be presented here (Fig. 1a and b). Temperature and solar flux increased after 1st week of February which promoted dispersion of the pollutants. Relative humidity also slightly decreased after 1 st week of February. $\mathrm{SO}_{2}$ and $\mathrm{O}_{3}$ considerably increased after 1 st week of February. The increase in $\mathrm{SO}_{2}$ is attributed to the reduced scavenging and low relative humidity. Increase in $\mathrm{O}_{3}$ is attributed to higher photo-chemical oxidation reaction due to higher incoming solar radiation (Fig. 1b). Lower $\mathrm{O}_{3}$ concentrations during foggy episode may also be attributed to phase transfer of $\mathrm{O}_{3}$ gas into the fog droplets which is the only aqueous source of $\mathrm{O}_{3}$ into the fog droplets (Herrmann et al., 2005). The decreased CO concentration after 1st week of February is attributed to higher boundary layer height and subsequent dispersion due to disappearance of the calm conditions by then.

\subsection{Positive matrix factorization (PMF) source apportionment}

Positive matrix factorization (PMF) analysis was carried out using EPA-PMF V3.0 to better understand the sources of the emission. The detailed information of the EPA-PMF V3.0 is available at http://www.epa.gov/heasd/products/pmf/pmf.html (Paatero, 1997, 1999; Paatero and Tapper, 1994). It requires concentration profile, detection limit and uncertainty profile as input. Model outputs are factor profiles, relative

\section{Relationship between organic and inorganic content of the aerosol}

D. S. Kaul et al.

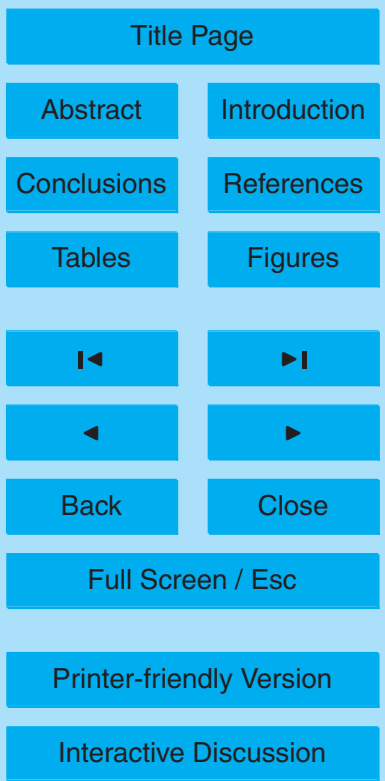


factor contribution and residuals. Following species were considered for the source apportionment: $\mathrm{Na}^{+}, \mathrm{NH}_{4}^{+}, \mathrm{K}^{+}, \mathrm{Ca}^{2+}, \mathrm{Cl}^{-}, \mathrm{SO}_{4}^{2-}$ and water soluble organic carbon (WSOC). The $\mathrm{F}^{-}$was not considered in the source apportionment because this species was detected only in January and 1st week of February. $\mathrm{Mg}^{2+}$ and water soluble inor5 ganic carbon (WSIC) were not considered due to a few missing values. $\mathrm{NO}_{3}^{-}$was not considered because this species was comparatively heavily scavenged during foggy episodes and could not be modeled by PMF with reliable certainty. The few missing concentrations of the species considered $(\sim 1-5)$ were replaced with their mean concentration as some investigators have obtained betters results such as improved 10 factors profiles with the mean concentrations (Huang et al., 1999; Reff et al., 2007). Uncertainty of the ionic species introduced by the blank and change in the calibration over the analysis period was estimated and considered. Total uncertainty was estimated by taking root mean square of the uncertainties in the blank and change in the calibration. Uncertainty for WSOC was based on only blank measurement. The total 15 uncertainty (ionic species and WSOC) was found to be less that $16 \%$. Uncertainty introduced due to several other factors such as ultrasonication process and extraction procedures, sampling etc. could not be included.

Detection limit of the EC-OC analyzer is $0.2 \mu \mathrm{g} \mathrm{cm}^{-2}$ of the filter area. This limit was divided by sampled volume of the air to convert it into $\mu \mathrm{g} \mathrm{m}^{-3}$ of the air. Detection limit of 20 the TOC analyzer and the lon Chromatograph are $4 \mathrm{ppb}$ and $1 \mathrm{ppb}$, respectively. These units were also appropriately converted into $\mathrm{g} \mathrm{m}^{-3}$ of the air. The concentrations below the limit of detection (LOD) (in a few samples only $\sim 1-3$ ) were replaced with half of the limit of detection (LOD) value. The uncertainty for the missing concentrations and concentrations below the LOD concentrations were 4 and $4 / 5$ times the concentration 25 (Polissar et al., 1998). Guidelines related to the signal to noise $(S / N)$ ratio for assigning the species such as strong or weak depends upon the relative $S / N$ ratio of the other species. The $S / N$ ratios of most of the species were less than 2 and none had less than 0.2 . Thus, all the species were categorized as weak. More details on classification of the species as strong or weak are in (Paatero and Hopke, 2003).

\section{Relationship between organic and inorganic content of the aerosol}

D. S. Kaul et al.

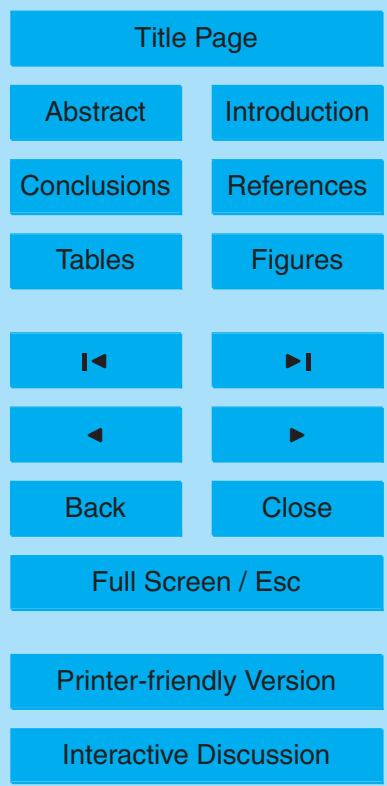


An appropriate protocol at every step such as choosing number of the factors, observing the similar Q-values of several runs, the solution space of the factors (GSpace), the regression coefficients between measured and modeled values etc. was followed to arrive at the acceptable solution (Reff et al., 2007) through several trial and errors. An appropriate number of the factors between 3 and 7 were tried and depending upon the Q-values and physical meaning of the profile, 4 factors were chosen which represented the relevant profile of the sources. Lesser or greater than 4 either combined or produced too many sources to make any physical sense. A few samples (5) associated with some events recording higher concentrations of almost all the species

such as excess biomass burning events were considered as outlier and were not used in the PMF analysis as these events will not be captured by the PMF. The regression coefficients between measured and modeled concentrations of the species were more than 0.96 for all the species except for $\mathrm{SO}_{4}^{2-}$ and $\mathrm{K}^{+}$which were 0.66 and 0.20 , respectively. $\mathrm{K}^{+}$was modeled poorly because of its scavenging and wet removal from

15 the atmosphere. $\mathrm{K}^{+}$could not be excluded from the analysis because this was the only tracer for the biomass emissions.

Emission sources were resolved into four factors viz. F1 - biomass burning, F2 refractory source, F3 - secondary source and F4 - mineral dust source. Only positive contribution to each sample, ignoring a few negative contributions, is included in the figures (Figs. S2 to S5). F1 is characterized by $\mathrm{K}^{+}$and WSOC which are mainly emitted from the biomass sources (Fig. S2). F2 is characterized by the refractory species which are emitted at higher temperature such as $\mathrm{Na}^{+}, \mathrm{Cl}^{-}$and $\mathrm{Ca}^{2+}$ (Fig. S3). F3 is characterized by the secondary species such as $\mathrm{SO}_{4}^{2-}$ and $\mathrm{NH}_{4}^{+}$(Fig. S4). $\mathrm{F} 4$ is characterized by the mineral dust comprising mainly of $\mathrm{Ca}^{2+}, \mathrm{Na}^{+}, \mathrm{K}^{+}$(Fig. S5).

\subsection{Chemical properties during foggy and nonfoggy episodes}

Concentration of $\mathrm{PM}_{1}$ was observed to be relatively lesser during foggy episode. The study average $\mathrm{PM}_{1}$ mass concentrations during foggy and nonfoggy episode were

\section{ACPD}

12, 14483-14524, 2012

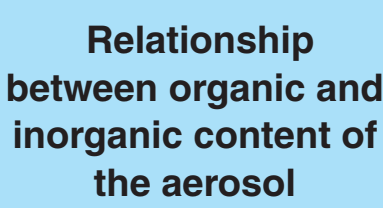

D. S. Kaul et al.

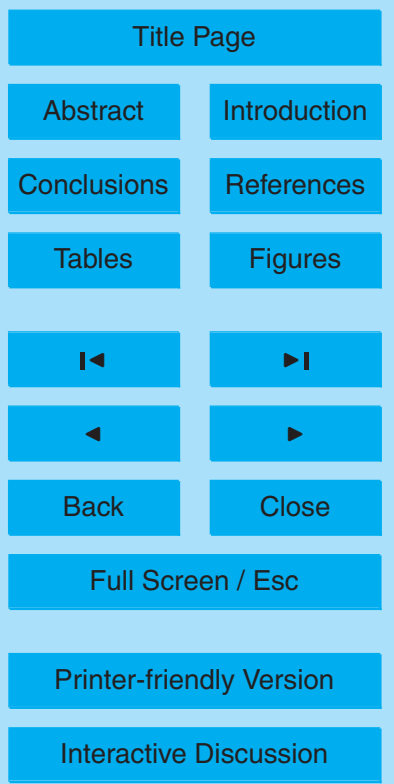


$427.3 \pm 209.5 \mathrm{\mu g} \mathrm{m}^{-3}$ and $525.6 \pm 261 \mathrm{\mu g} \mathrm{m}^{-3}$, respectively. The lower concentration during foggy episode may be attributed to scavenging by the fog droplets. The secondary organic aerosol (SOA) accounted for $\sim 11.6$ and $\sim 7 \%$ of total particulate mass $\left(\mathrm{PM}_{1}\right)$ during foggy and nonfoggy episode, respectively. The primary organic aerosol 5 (POA) accounted for $\sim 7.0$ and $\sim 6.5 \%$ of total particulate mass $\left(\mathrm{PM}_{1}\right)$ during foggy and nonfoggy episode, respectively. Most of the aerosol was composed of inorganic components, $\sim 80 \%$ during foggy episode and $\sim 86 \%$ during nonfoggy episode (Fig. $2 \mathrm{~b}$ and c).

Optical and microphysical properties depend on the chemical composition of the 10 aerosols. For example, investigators (Lee and Sequeira, 2002; Sun et al., 2006; Ulevicius et al., 1994) have shown the role of ionic species of the aerosols on the visibility reduction and growth of the organic aerosols processed by the aqueous chemistry (Trainic et al., 2011). To examine such effects, in addition to aerosol chemistry during foggy and nonfoggy episodes, fogwater chemistry was also examined. The average concentrations of almost all the anionic and cationic species in the aerosols were higher during foggy episode (Fig. $3 a$ and $b$ ). The higher average concentration of the crustal elements $\left(\mathrm{Ca}^{2+}\right.$ and $\left.\mathrm{Mg}^{2+}\right)$ during foggy episode may be attributed to relatively low boundary layer during the period and subsequent accumulation of the mineral dust particles. The average boundary layer during foggy episode was lesser than nonfoggy episode which is documented in our previous study (Kaul et al., 2011). PMF resolved sources show that small amount of $\mathrm{Ca}^{2+}$ is associated with the mineral dust; its other major sources include biomass and refractory. The higher average concentration of $\mathrm{SO}_{4}^{2-}$ and $\mathrm{NH}_{4}^{+}$during foggy episodes is due to their secondary production by aqueous mechanism where precursor gaseous species $\left(\mathrm{NH}_{3}, \mathrm{SO}_{2}\right)$ are dissolved in the fog droplets due to their higher water solubility depending upon the acidic or basic nature of the fog droplets. Their subsequent oxidation to $\mathrm{SO}_{4}^{2-}$ and $\mathrm{NH}_{4}^{+}$by the dissolved oxidizing agents such as $\mathrm{O}_{3}, \mathrm{H}_{2} \mathrm{O}_{2}, \mathrm{OH}$ radical and accumulation on the interstitial particle is the primary production mechanism which leads to their higher concentrations in the aerosols during foggy episode (Fig. $3 a$ and b). PMF resolved sources show that small

\section{Relationship between organic and inorganic content of the aerosol}

D. S. Kaul et al.

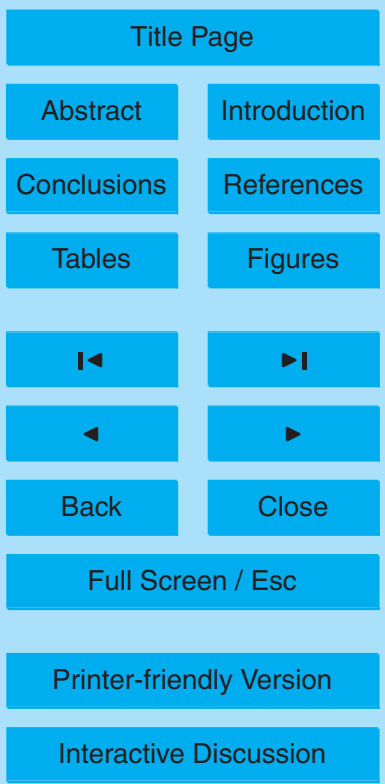


amount can also be emitted from the other sources such as refractory, biomass and dust (Figs. S2 to S5) in addition to their major secondary production. Although, the average $\mathrm{NO}_{3}^{-}$concentration during foggy episodes was observed to be lower which may be attributed to its higher scavenging as exemplified by its higher concentration in 5 the fogwater and relatively higher water solubility (Fig. 4). The enhanced scavenging of $\mathrm{NO}_{3}^{-}$can be attributed to its secondary and biomass burning origin (Figs. S2 and S4) as the generated aerosols from these sources are highly water soluble. The higher water solubility of biomass burning generated aerosol and aged aerosols has been documented in a recent article (Pratt et al., 2011). Similar higher values of both the anionic 10 and cationic species in the aerosol during fog-haze episodes has been documented earlier (Sun et al., 2006) which results from the dust transport and accumulation of these particles due to poor dispersion. The higher average concentration of secondary ions $\mathrm{NO}_{3}^{-}, \mathrm{SO}_{4}^{2-}$ and $\mathrm{NH}_{4}^{+}$and other ions in the fogwater was observed indicating their wet removal from the atmosphere (Fig. 4). The higher average concentration of ionic 15 species in the smaller fog droplets indicates that smaller droplets are more enriched with ionic species due to their longer residence time as well as higher surface area offered for greater adsorption (Fig. 4).

Factor F2 indicates that most of the $\mathrm{Na}^{+}$and $\mathrm{Cl}^{-}$are emitted from the refractory sources (Fig. S3). Presence of $\mathrm{Cl}^{-}$and $\mathrm{F}^{-}$in the aerosols and their higher regression coefficient with $\mathrm{Na}^{+}$( $\sim 0.70$ and 0.55 , respectively) indicates its contribution from the refractory sources, although $\mathrm{Cl}^{-}$may also be emitted from biomass burning. Emission of $\mathrm{Cl}^{-}$as sea salt is negligible as the current sampling site location is too far from the nearest ocean. The higher concentration of $\mathrm{Cl}^{-}$and $\mathrm{F}^{-}$during foggy episode also indicates accumulation of these species due to lower boundary layer and calm atmospheric conditions (Fig. 1) during foggy episodes.

Kaul et al. (2011) have earlier documented that foggy conditions lead to enhanced SOA production through the aqueous phase process. Mass fraction of carbonaceous species such as POA, SOA are higher during foggy episode; although, the concentration of POA during foggy day was lesser due to the scavenging and wet removal by the

\section{Relationship between organic and inorganic content of the aerosol}

D. S. Kaul et al.

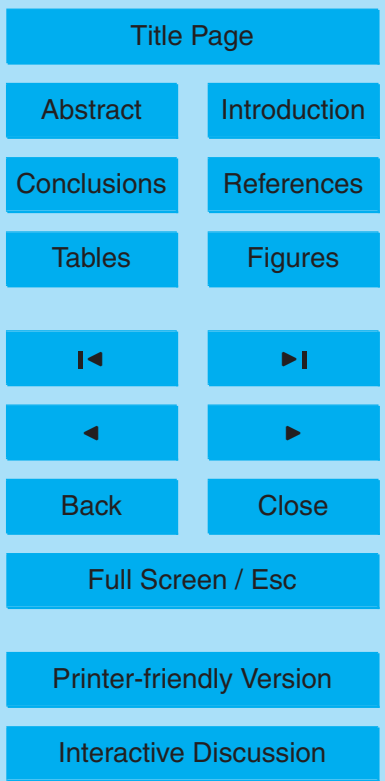


fog droplets. The scavenging of elemental carbon which acts as a tracer for POA has also been documented in recent articles (Wang et al., 2012; Kaul et al., 2011). Such removal could be due to their aged state and internal mixing in which they become quite hygroscopic. POA and SOA account for relatively small portion of the total $\mathrm{PM}_{1}$ mass

5 during both foggy and nonfoggy episode (Fig. $2 b$ and c). SOA is mostly composed of the oxygenated organic compounds which are water soluble (Aiken et al., 2008; Ng et al., 2011). Thus, WSOC can work as SOA tracer provided contribution of WSOC to SOA from other sources is negligible. Most of the WSOC is observed to come from biomass burning and the contribution from the secondary source is relatively small 10 (Figs. S2 to S5). Although, biomass burning and secondary source combined together are the major sources of WSOC. This PMF resolved source contribution of WSOC is in tandem with SOA estimate (Fig. $2 \mathrm{~b}$ and c) which does not contribute considerably to the total mass of the aerosol during both foggy and nonfoggy episode. Although, several investigators have previously documented relatively larger fraction of organic carbon

15 ( 20-90\%) (Jimenez et al., 2009; Kanakidou et al., 2005; Zhang et al., 2007), this study found $\mathrm{PM}_{1}$ to be mostly composed of inorganic aerosols with organic aerosol accounting for only $\sim 19$ and $13 \%$ during foggy and nonfoggy episode, respectively (Fig. 2). This is an interesting finding typical of this part of the world.

\subsection{Temporal variation of chemical properties}

$20 \mathrm{Ca}^{2+}, \mathrm{Na}^{+}$and $\mathrm{NH}_{4}^{+}$show considerable reduction in concentration after 1 st week of February month (Fig. 5) which may be attributed to increased dispersion and reduced secondary production. The higher $\mathrm{NH}_{4}^{+}$concentration during January and early February may be attributed to favorable atmospheric conditions such as low temperature and higher relative humidity (Fig. 1b) which enable easy conversion of $\mathrm{NH}_{3}$ to $\mathrm{NH}_{4}^{+}$. 25 Although, similar drastic reduction in $\mathrm{K}^{+}$and $\mathrm{Mg}^{2+}$ concentration was not observed (Fig. 5). $\mathrm{K}^{+}$generally acts as a biomass tracer which can be used to deduce the influence of biomass burning on aerosol during these months, although $\mathrm{K}^{+}$emitted from the other sources such as mineral and soil dust can contaminate those emitted from

\section{Relationship between organic and inorganic content of the aerosol}

D. S. Kaul et al.

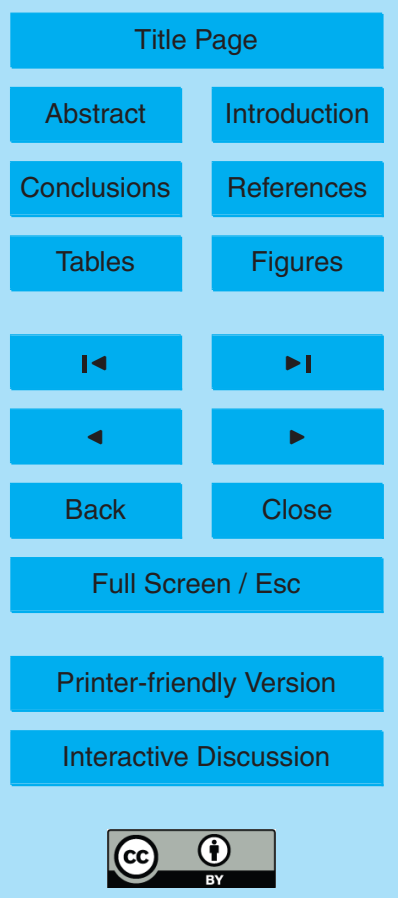


biomass burning (Duvall et al., 2008). Temperature had slightly increased by the late February (Fig. 1b) which pleases people to burn less biomass due to reduced severe cold conditions. Thus, $\mathrm{K}^{+}$concentration is expected to decrease during February. The lesser concentration of $\mathrm{K}^{+}$during January despite relatively more biomass burning may 5 rather be attributed to the scavenging and wet removal of $\mathrm{K}^{+}$during foggy episode as biomass emitted aerosols are highly hygroscopic. The removal is also exemplified by the lesser average concentration of $\mathrm{K}^{+}$during foggy episode (Fig. 3b) and presence of $\mathrm{K}^{+}$in the fogwater (Fig. 4b). Similar removal of WSOC and $\mathrm{K}^{+}$is also documented elsewhere (Kaul et al., 2011) and considerable biomass source of WSOC and $\mathrm{K}^{+}$during 10 foggy episode further supports the cause (Fig. S2). The factor F1 - biomass burning during foggy episode seems to contribute relatively more during late February which is due to reduced scavenging in the absence of fog (Fig. S2). Atmospheric conditions during both foggy and nonfoggy episodes were mostly calm (Kaul et al., 2011) which indicates their anthropogenic and local emissions. Thus, higher relative contribution of 15 biomass after 1st week of February could not be attributed to its distant source and long range transport.

The notable reduction in the concentrations of $\mathrm{Ca}^{2+}$ and $\mathrm{Na}^{+}$from January and early February to late February may be attributed to clear conditions and subsequent dispersion of the mineral dust and refractory produced species. Concentration of $\mathrm{Cl}^{-}$ and $\mathrm{F}^{-}$shows considerable decrease from January to February and $\mathrm{F}^{-}$was found to be absent during most of the February month, although $\mathrm{Cl}^{-}$was present during this period (Fig. 6). $\mathrm{Cl}^{-}$may be emitted from the coal combustion and biomass burning. $\mathrm{Cl}^{-}$ emission from the sea salt is negligible because of the site being remotely located from the nearest ocean. $\mathrm{F}^{-}$may be emitted from the coal combustion, aluminum smelters, phosphate fertilizers factories, brick yards and glass work (Haidouti et al., 1993). The major emission sources of $\mathrm{F}^{-}$near the sampling site are mainly the coal combustion and brick-kilns. Coal is also used in the brick kilns. This indicates that January which is mostly influenced by foggy conditions is affected by emissions from the refractory sources considerably. $\mathrm{SO}_{4}^{2-}$ also shows higher concentration during January

\section{ACPD}

$12,14483-14524,2012$

\section{Relationship between organic and inorganic content of the aerosol}

D. S. Kaul et al.

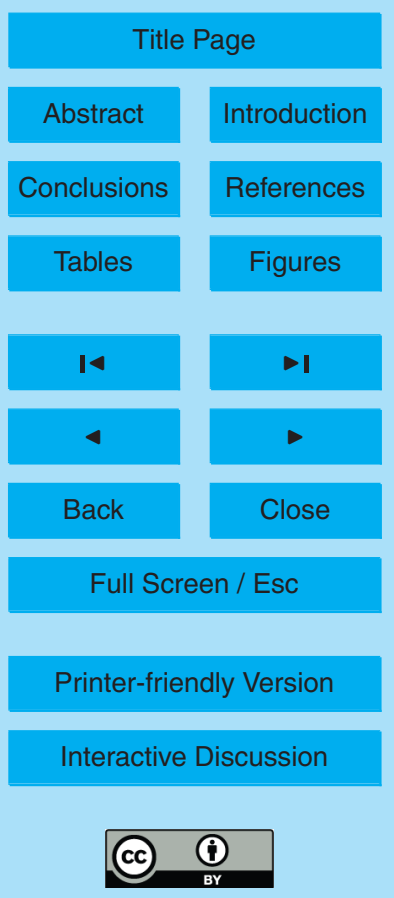


and concentration decreases in February (Fig. 6). The higher relative humidity and lower temperature during January and early February periods (Fig. 1b) seems to favor more sulfate production through aqueous mechanism. Considerable amount is also observed to come from the refractory, biomass and dust origin (Figs. S2-S5). $\mathrm{SO}_{4}^{2-}$ 5 shows enormous variation in comparison to the other anionic species. $\mathrm{SO}_{4}^{2-}$ shows large reduction in concentration after 1 st week of February and the trend was opposite to that of $\mathrm{NO}_{3}^{-}$. Such pattern of $\mathrm{SO}_{4}^{2-}$ could be attributed to its different source and lesser scavenging and wet removal rate; although, secondary and biomass accounts for considerable portion ( $75 \%)$, substantial portion is also being emitted from the other sources ( $25 \%)$ which might be relatively less water soluble. $\mathrm{NO}_{3}^{-}$was lower during January and relatively higher during February (Fig. 6). The reduced concentrations could be due to its scavenging by the fog droplets. Contribution of $\mathrm{NO}_{3}^{-}$is mostly from the secondary origin which is water soluble. $\mathrm{NO}_{3}^{-}$also has higher water solubility than $\mathrm{SO}_{4}^{2}$ which could be the other reason for drastic reduction in its concentration in 15 January.

WSOC and WSIC both show considerably lower concentrations during January which increases significantly in February. Such low concentrations during January are possibly due to their scavenging by the fog droplets (Fig. 7). The scavenging of WSOC has also been documented earlier (Kaul et al., 2011). SOA is higher during January and early February and decreases during most of the February. POA is relatively lesser during January and early February, concentration seems to have increased in the February (Fig. 7). $\mathrm{PM}_{1}$ mass concentration did not change considerably after 1st week of February (Fig. 2a).

\subsection{Processing between inorganics and organics of fog droplet and aerosol}

25 Fog droplets process organics and inorganics. Such processing is exemplified by the presence of various inorganic species (Fig. 4), organic carbon (OC) (Kaul et al., 2011) and inorganic carbon (IC) in the fog droplets (Fig. 4 and Table S6a). The average

\section{ACPD}

$12,14483-14524,2012$

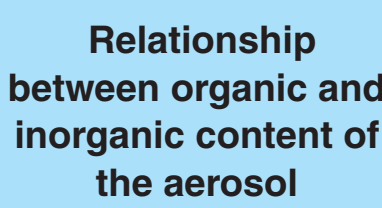

D. S. Kaul et al.

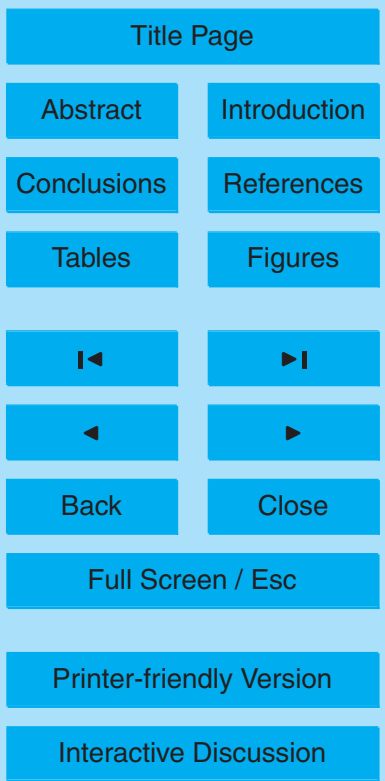


inorganic carbon content of the fog droplets of size $22-16 \mu \mathrm{m}, 4-16 \mu \mathrm{m}$ and $<4 \mu \mathrm{m}$ were $5.1 \pm 6.0,13 \pm 10.6$ and $16.5 \pm 20.20 \mathrm{mg} \mathrm{I}^{-1}$, respectively. It is clear that smaller sized fog droplets are more enriched with inorganic carbon, similar trend was also observed for organic carbon of the fog droplets which is documented elsewhere (Kaul 5 et al., 2011).

The correlation of $\mathrm{OC}$ and IC of the fog droplets with inorganic species of the fog droplets was examined to explore the role of inorganic species in scavenging of organics and vice versa and formation of organo-sulfate and organo-nitrate inside the fog droplets. Formation of organo-sulfate and organo-nitrate can be exemplified by 10 the better correlation of organics with sulfate and nitrate (Xiao et al., 2009; Gao et al., 2004). The correlation coefficient of organic carbon and inorganic carbon content with inorganic species is shown in Table S7. From this table, it is clear that scavenging characteristics of different sized fog droplets are different. Organic carbon of the fog droplets is better correlated with almost all the inorganic species of all fog droplets 15 size except with secondary inorganic species such as $\mathrm{SO}_{4}^{2-}, \mathrm{NH}_{4}^{+}$and $\mathrm{NO}_{3}^{-}$which are better correlated with organic carbon of smaller fog droplets $(4-16 \mu \mathrm{m}$ and $<4 \mu \mathrm{m})$. The higher correlation of organic carbon with sulfate and nitrate indicates formation of organo-sulfate and organo-nitrate in smaller fog droplets only. The better correlation of $\mathrm{OC}$ with biomass and refractory originated species indicates that these sources also contribute to carbon content of the fog droplets. It can also be inferred from the source profiles of biomass and refractory (Figs. S2 and S3) which contributed to WSOC. Inorganic carbon is only correlated within fog droplets of size 4-16 $\mu \mathrm{m}$ which indicates that IC actively interact only within $4-16 \mu \mathrm{m}$ fog droplets size. Since most of the IC is coming from the carbonates of $\mathrm{Ca}^{2+}$ and $\mathrm{Mg}^{2+}$ etc. It is likely that these fog droplets of 4-16 $\mu \mathrm{m}$ size only condenses over dust originated aerosol which are mostly carbonates of $\mathrm{Na}^{+}, \mathrm{NH}^{+}, \mathrm{K}^{+}, \mathrm{Ca}^{2+}, \mathrm{Mg}^{2+}$ etc. A fair correlation of IC with these ions does indicate presence of their carbonates (Table S7).

The preferential higher concentration of $\mathrm{SO}_{4}^{2-}, \mathrm{NH}_{4}^{+}$and $\mathrm{NO}_{3}^{-}$in smaller fog droplets and their higher correlation with $\mathrm{OC}$ could be attributed to higher phase transfer and

\section{ACPD}

$12,14483-14524,2012$

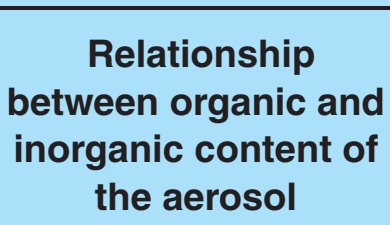

D. S. Kaul et al.

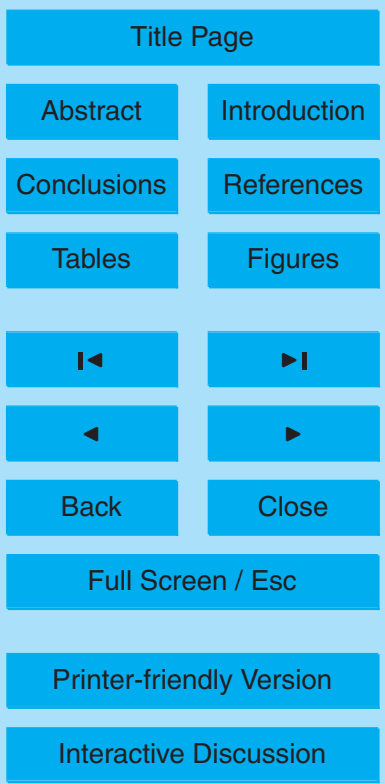

\section{0}


accommodation coefficient into the smaller size fog droplets. Processing of organics by sulfate and ammonium in the aqueous phase and subsequent production of the organo-sulfate and organo-nitrogen compounds in the aerosols have been previously documented elsewhere (Noziere et al., 2008; Perri et al., 2010; Galloway et al., 2009; 5 Kua et al., 2011; Shapiro et al., 2009). The correlation of SOA with sulfate and nitrate concentration of aerosols during foggy episode was rather poor $\left(R^{2} \sim 0.24\right.$ and $\sim 4.0 E-5$, respectively). This indicates that organo-sulfate and organo-nitrate stay in the liquid phase of the fog droplets due to their higher water solubility and are wet scavenged overnight. The formation of organo-sulfate and organo-nitrate in the 10 aerosols was further examined in the evaporating fog. The SOA, sulfate and nitrate measurements of morning (07:30 a.m.) to 13:30 p.m. were only considered to evaluate the influence of evaporation on their subsequent formation. The poor regression coefficient of SOA with sulfate and nitrate in evaporating fog $\left(R^{2} \sim 0.24\right.$ and $\sim 0.02$ respectively) also shows their negligible production. Thus, contribution of organo-sulfate and organo-nitrate to $\mathrm{PM}_{1}$ mass seems to be negligibly small. Recent work (Stone et al., 2012) over several places in Asian region has also documented formation of organo-sulfate and orgno-nitrate to be negligibly small ( $<1 \%$ of particulate mass). The likely formation of organo-sulfate and organo-nitrate inside the fog droplets but their absence in the aerosol of evaporating fog may also indicate their overnight scavenging and wet removal. The other most likely reason for their observed absence could be due to presence of mostly inorganic sulfate and nitrate which could be hardly attached with oxygenated organic compounds.

\subsection{Acidity of aerosols and secondary organic aerosol (SOA)}

Dust originated ions such as $\mathrm{Ca}^{2+}$ and $\mathrm{Mg}^{2+}$ contribute negligibly to acidity of the 25 aerosols. $\mathrm{Cl}^{-}$which is highly correlated with $\mathrm{Na}^{+}$indicates that most of the $\mathrm{Cl}^{-}$is consumed by $\mathrm{Na}^{+}$and $\mathrm{Cl}^{-}$is available negligibly to contribute to acidity of the aerosols. Similar observation on contribution of $\mathrm{Ca}^{2+}, \mathrm{Mg}^{2+}$ and $\mathrm{Cl}^{-}$to acidity of the aerosols has also been documented elsewhere (Pathak et al., 2004). Thus, three major ions 14501

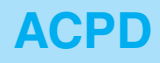

12, 14483-14524, 2012

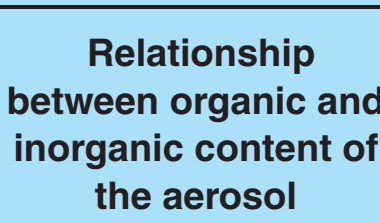

D. S. Kaul et al.

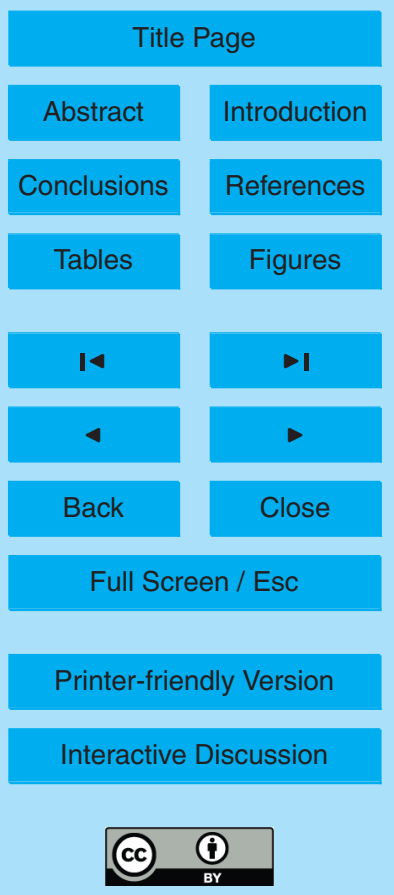


$\mathrm{NH}_{4}^{+}, \mathrm{SO}_{4}^{2-}$ and $\mathrm{NO}_{3}^{-}$have been considered to evaluate the acidity of the aerosols which is defined as $\mathrm{J}=\mathrm{NH}_{4}^{+} /\left(2 \mathrm{SO}_{4}^{2-}+\mathrm{NO}_{3}^{-}\right)$. A correlation between $\mathrm{J}$ and OC/EC can show the effect of acidity on SOA formation (Fig. S7). It can be seen from this figure that regression coefficient is poor $\left(R^{2} \sim 0.01\right)$. Regression coefficients were also poor

5 during foggy, nonfoggy episode and after 1st week of February. Thus, over the study region, acidic condition does not seem to produce higher SOA.

\subsection{Microphysical properties during foggy and nonfoggy episodes and its temporal variation}

The study average diurnal number, volume and surface size distributions of aerosols during the sampling periods were similar except that diurnal variation in concentrations, geometric standard deviation (GSD) and modal diameter (Dm) was observed. Thus, a typical figure (Fig. 8a) during 11:00 a.m. to 01:30 p.m. sampling duration is presented to represent the average distribution during other sampling durations. To capture the diurnal changes during the other sampling durations, the study average 15 total concentration of aerosols, modal diameter and geometric standard deviation have been shown in Fig. 8b. Figure 8a shows presence of ultrafine particles in higher number and volume during foggy episodes. The shift in the mode toward larger size during foggy episodes was observed which is due to the growth of the particles during fog events and aerosol ageing (Fig. 8b); GSD was less indicating dominance of narrow size 20 range of particles during foggy episodes (Fig. $8 \mathrm{~b}$ ). The narrow size range may be due to the removal of larger size particles by fog droplets. The higher number and volume concentration during foggy episode can be attributed to reduced boundary layer (especially during late evening and overnight) and condensation of semi-VOCs whereas during day preferably during 07:30 a.m. to 01:30 p.m. sampling period when fog evaporation takes place, aqueous phase production of SOA combined with gas to particle partioning can contribute to such cause. As the day evolves, boundary layer will bring the aerosol concentration down due to dispersion, but from this figure (Fig. 8b), the

\section{Relationship between organic and inorganic content of the aerosol}

D. S. Kaul et al.

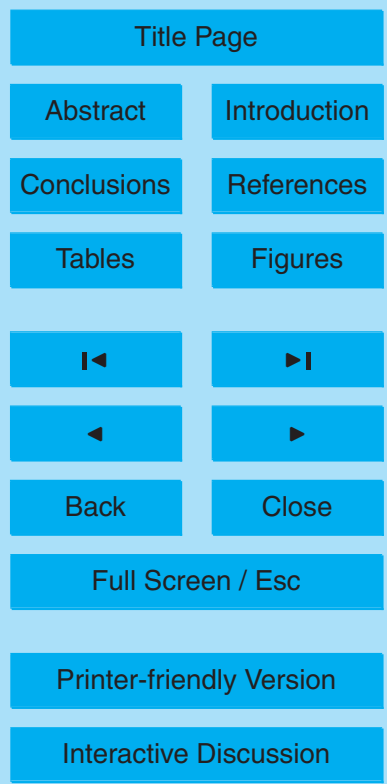


total concentration and median diameter from 9 LST to 12.3 LST (LST is local standard time) has slightly increased (Fig. 8b). As fog droplets evaporates, it leave dissolved aqueous oxidized organic compounds behind which may form new particles by nucleation process or may partition on to the preexisting aerosols. Fog evaporation and 5 subsequent SOA production have been documented in our previous study (Kaul et al., 2011). These two processes will increase both particle diameter and volume of the aerosols. The particle diameter growth rate which was calculated following procedure described elsewhere (Ulevicius et al., 1994) during fog evaporation and fog formation is shown in Figs. S9 and S10, respectively. Figure S9a shows the particle diameter 10 growth rate from overnight $(\sim 2.6 \mathrm{LST})$ to $9 \mathrm{LST}$. It is clear from this figure that smaller particles (diameter less than $100 \mathrm{~nm}$ ) show growth in diameter which could be due to condensation of the oxygenated semi- VOCs over the pre-existing aerosols whereas larger particles (diameter greater than $100 \mathrm{~nm}$ ) have negative growth rate which could be attributed to evaporation of the fog droplets. The particle diameter growth rate from 159 LST to 12.3 LST is shown in Fig. S9b. The growth rate of particles of diameter less than $100 \mathrm{~nm}$ during fog evaporation is attributed to condensation of oxygenated semiVOCs on the pre-existing aerosols whereas the diameter growth above $100 \mathrm{~nm}$ can be attributed to aqueous phase formation of secondary organic aerosols. It is also seen from this figure that growth rate of diameter greater than $300 \mathrm{~nm}$ increases with diameter which is the characteristic of aqueous phase formation of secondary aerosols. Some investigators (Ulevicius et al., 1994) have also documented fog evaporation and subsequent growth in diameter of particles below $100 \mathrm{~nm}$ due to condensation of semiVOCs and above $100 \mathrm{~nm}$ due to the aqueous phase formation of secondary aerosols. Similar evolution of number and mass from photo oxidation of semi volatile compounds have been reported elsewhere (Adler et al., 2011; Wang et al., 2011a, b; Kerminen and Wexler, 1995; Maria et al., 2004).

Fog formation from evening to late night (Fig. S10a and b) also shows growth in particle diameter of all size. The growth rate from $\sim 16.2$ LST to $\sim 19.2$ LST and from $\sim 19.2$ LST to $\sim 22.3$ LST is distinctively different with transition period (i.e. from

\section{Relationship between organic and inorganic content of the aerosol}

D. S. Kaul et al.

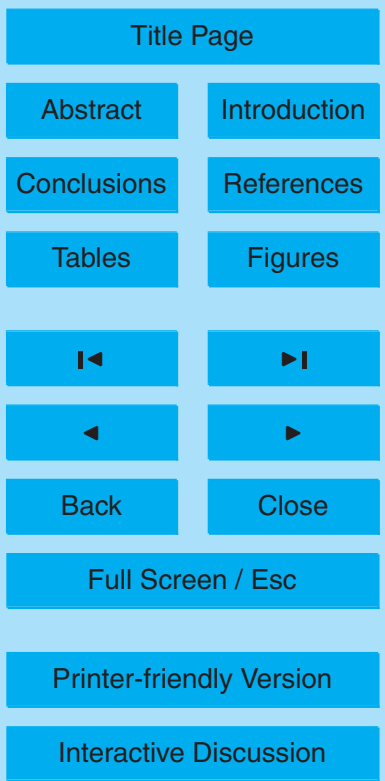


16.2 LST to 19.2 LST) showing highest diameter growth rate during fog formation. During transition period of fog evaporation (i.e. 2.3 LST to $9 \mathrm{LST}$ ), the smaller particles showed relatively higher diameter growth rate.

Secondary inorganic aerosols (ammonium sulfate, nitrate) formation, as fog is evap5 orating, is compared at three local standard time (LST) i.e. 2.3, 9 and 13.3 LST to observe their role on particle diameter growth rate. Ammonium and sulfate does show substantial increase from overnight (i.e. 2.3 LST) to 9 and 12.3 LST. Similar increase of nitrate as fog evaporates was not observed (Table S8). Nitrate is mostly produced during night time. The almost similar concentrations of nitrate at 2.3, 9 and 13.3 LST can indicate production of nitrate during fog evaporation otherwise its concentration at 9 and 13.3 LST would have been otherwise relatively smaller. Thus, aqueous phase secondary inorganic aerosol (ammonium, sulfate and nitrate) and organic aerosol formation (Kaul et al., 2011), both will contribute to aqueous phase production of aerosol. The high total number concentration during overnight and late evening during foggy 15 episode can be attributed to low boundary layer and accumulation of preexisting or new particles thus formed or fresh emission of particles. Refractory source emitted particles, which shows considerable influence during foggy episode as resolved by PMF (Fig. S3), may certainly influence particle concentration during early morning, late evening and overnight period. The refractory emitted particles are less hygroscopic and could have been poorly scavenged. The lowest concentration at $\sim 16$ LST is due the atmospheric dispersion (Fig. 8b); also fog by this time evaporates and almost disappears.

Aerosols mostly below $40 \mathrm{~nm}$ size seem to be weakly correlated with photo-oxidation and aqueous processes as exemplified by their lower number and volume concentration during foggy episodes which has otherwise been higher (Fig. 8a). These particles hardly contribute to the cloud and fog formation due to their primary emissions and fresh nature which is a poor cloud condensation nuclei (Fig. 8a). Thus their lower concentration may not be due to aerosol scavenging. These behaviors may be due to their

\section{Relationship between organic and inorganic content of the aerosol}

D. S. Kaul et al.

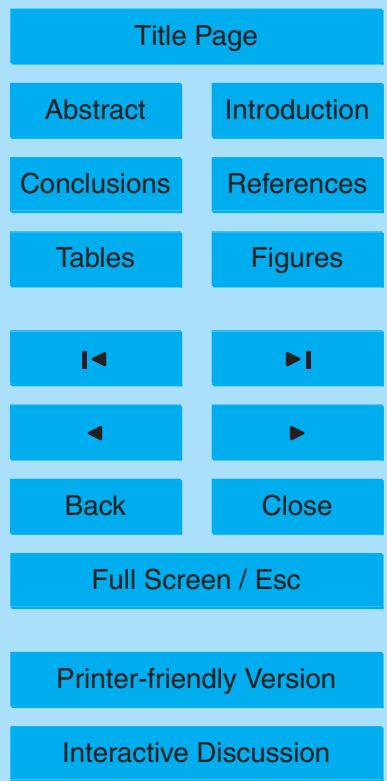


coagulation into larger sized aerosols which is favored due to lower temperature and higher relative humidity during fog episodes.

Total concentration of aerosols before 1st week of February is higher; concentration during late February seems to have fallen down. Such reduced concentration may 5 be attributed to facilitated dispersion. The median diameter of the aerosols before 1st week of February is though only slightly higher. Geometric standard deviation does show considerable increase in the late February (Fig. 9).

\section{Summary and conclusions}

Chemical properties of aerosols and fogwater such as inorganic and organic con10 stituents and microphysical properties of aerosols such as total number concentration, modal diameter and geometric standard deviation of the aerosols during foggy and nonfoggy episodes were measured during January and February 2010. Fogwater was analyzed for the organic and inorganic constituents. Positive matrix factorization (PMF), as a tool for the source apportionment was used to better understand the emission 15 sources. Four emission sources were resolved by PMF viz. biomass burning, refractory, secondary and mineral dust. The concentrations of almost all the ionic species in the aerosol were higher during foggy episodes. Presence of the numerous ionic species in the fogwater indicates their wet scavenging and removal from the atmosphere by the fog droplets. Despite their wet scavenging, most of the species in aerosols still have 20 higher concentration during foggy episode compared to nonfoggy episode, except $\mathrm{K}^{+}$, water soluble organic carbon (WSOC), water soluble inorganic carbon (WSIC) and $\mathrm{NO}_{3}^{-}$which had lower concentration during foggy episode. Higher scavenging of these species may be due to their biomass burning and secondary source origin as biomass and secondary generated aerosols are highly hygroscopic. $\mathrm{SO}_{2}$ was also wet scavenged by the fog droplets and concentration was lower during foggy episodes. WSOC comes mainly from both the secondary and the biomass burning. The smaller sized fog droplets were more enriched with these inorganic and organic species which has

\section{ACPD}

$12,14483-14524,2012$

\section{Relationship between organic and inorganic content of the aerosol}

D. S. Kaul et al.

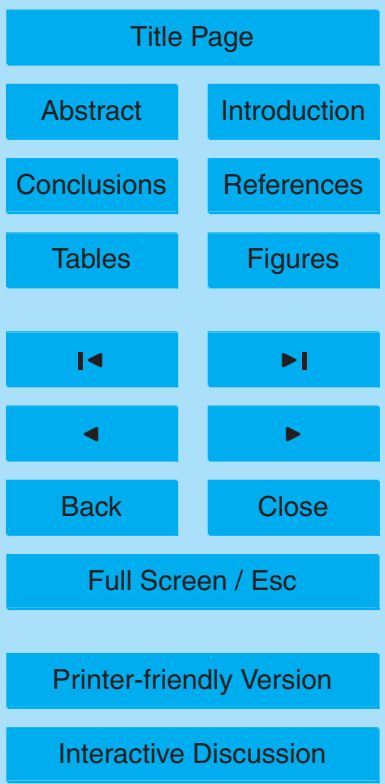


limited removal rate and larger surface area compared to the larger fog droplets. The study average secondary organic aerosol (SOA) accounted for $\sim 11.6$ and $\sim 7 \%$ of total particulate mass $\left(\mathrm{PM}_{1}\right)$ during foggy and nonfoggy episode respectively. The study average primary organic aerosol (POA) accounted for $\sim 7.0$ and $\sim 6.5 \%$ of total particulate 5 mass $\left(\mathrm{PM}_{1}\right)$ during foggy and nonfoggy episode respectively. Most of the aerosol was composed of inorganic components, $~ 80 \%$ during foggy episode and $\sim 85.5 \%$ during nonfoggy episode. Biomass burning contribution to the aerosol was considerably higher during nonfoggy episodes and lesser during foggy episodes; lower contribution was primarily due to wet scavenging of biomass burning generated aerosols. The relative contribution of all the sources except biomass burning was considerably higher during foggy and calm conditions, mostly before 1st week of February and relative contribution decreased considerably for all the sources except biomass burning which actually increased. Calm conditions till 1st week of February affected both microphysics and chemistry and aerosols considerably. The study average higher number of aerosol during foggy episode during late evening and overnight was due to lower boundary layer height and subsequent accumulation of freshly emitted, previously aged particles in the atmosphere. SOA production during fog evaporation caused increase in the number concentration and growth in size of the aerosols. The dissolved inorganic species play an important role in scavenging of organic compounds most likely due to the formation of organo-sulfate and organo-nitrate inside the fog droplets. The results indicated that the contribution of organo-sulfate and organo-nitrate to particulate mass was negligible. Acidity of the aerosols was also evaluated and negligible influence of acidity on secondary organic aerosol was observed.

\section{Supplementary material related to this article is available online at: http://www.atmos-chem-phys-discuss.net/12/14483/2012/ acpd-12-14483-2012-supplement.pdf.}

\section{ACPD}

12, 14483-14524, 2012

Relationship

between organic and inorganic content of the aerosol

D. S. Kaul et al.

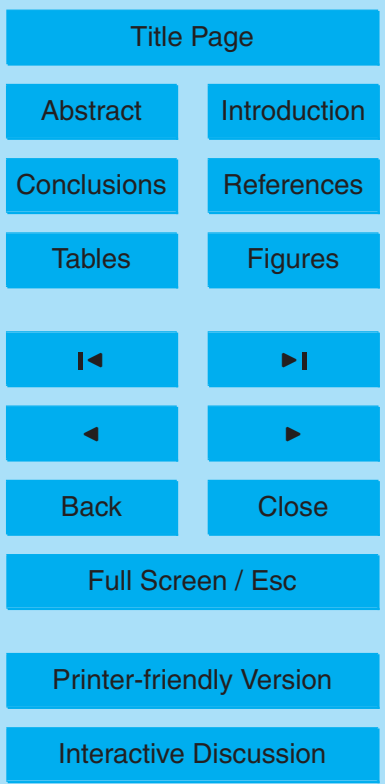


Acknowledgements. We thank MPL network (MPLnet) Judd Welton, NASA and staff for their effort in maintaining the Kanpur MPLnet site. We thank Brent Holben and staff for establishing and maintaining AERONET at Kanpur. We also thank Jai Prakash, Rajmal Jat, Vaishali Ashok, Abhishek Gaur and Soumabha Chakroborty for their help in this extensive field measurement.

\section{References}

Adler, G., Flores, J. M., Abo Riziq, A., Borrmann, S., and Rudich, Y.: Chemical, physical, and optical evolution of biomass burning aerosols: a case study, Atmos. Chem. Phys., 11, 14911503, doi:10.5194/acp-11-1491-2011, 2011.

Aikawa, M., Hiraki, T., Suzuki, M., Tamaki, M., and Kasahara, M.: Separate chemical characterizations of fog water, aerosol, and gas before, during, and after fog events near an industrialized area in Japan, Atmos. Environ., 41, 1950-1959, 2007.

Aiken, A. C., DeCarlo, P. F., Kroll, J. H., Worsnop, D. R., Huffman, J. A., Docherty, K. S., Ulbrich, I. M., Mohr, C., Kimmel, J. R., Sueper, D., Sun, Y., Zhang, Q., Trimborn, A., Northway, M., Ziemann, P. J., Canagaratna, M. R., Onasch, T. B., Alfarra, M. R., Prevot, A. S. H., Dommen, J., Duplissy, J., Metzger, A., Baltensperger, U., and Jimenez, J. L.: O/C and OM/OC Ratios of Primary, Secondary, and Ambient Organic Aerosols with High-Resolution Time-of-Flight Aerosol Mass Spectrometry, Environ. Sci. Technol., 42, 4478-4485, doi:10.1021/es703009q, 2008.

Behera, S. N., and Sharma, M.: Reconstructing Primary and Secondary Components of $\mathrm{PM}_{2.5}$ Composition for an Urban Atmosphere, Aerosol Sci. Tech., 44, 983-992, 2010.

Berkowitz, C. M., Berg, L. K., Yu, X.-Y., Alexander, M. L., Laskin, A., Zaveri, R. A., Jobson, B. T., Andrews, E., and Ogren, J. A.: The influence of fog and airmass history on aerosol optical, physical and chemical properties at Pt. Reyes National Seashore, Atmos. Environ., 45, 2559-2568, 2011.

Birch, M. E. and Cary, R. A.: Elemental Carbon-Based Method for Monitoring Occupational Exposures to Particulate Diesel Exhaust, Aerosol Sci. Tech., 25, 221-241, 1996.

Blando, J. D. and Turpin, B. J.: Secondary organic aerosol formation in cloud and fog droplets: a literature evaluation of plausibility, Atmos. Environ., 34, 1623-1632, 2000.

Blando, J. D., Porcja, R. J., Li, T.-H., Bowman, D., Lioy, P. J., and Turpin, B. J.: Secondary Formation and the Smoky Mountain Organic Aerosol: An Examination of Aerosol Polarity
ACPD

12, 14483-14524, 2012

Relationship

between organic and

inorganic content of the aerosol

D. S. Kaul et al.

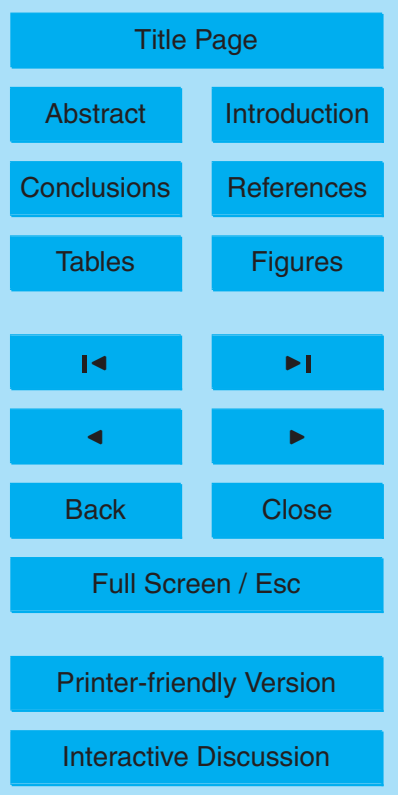


and Functional Group Composition During SEAVS, Environ. Sci. Technol., 32, 604-613, doi:10.1021/es970405s, 1998.

Bowman, F. M., Odum, J. R., Seinfeld, J. H., and Pandis, S. N.: Mathematical model for gasparticle partitioning of secondary organic aerosols, Atmos. Environ., 31, 3921-3931, 1997.

5 Cass, G. R.: On the relationship between sulfate air quality and visibility with examples in los angeles, Atmos. Environ., 13, 1069-1084, 1979.

Castro, L. M., Pio, C. A., Harrison, R. M., and Smith, D. J. T.: Carbonaceous aerosol in urban and rural European atmospheres: estimation of secondary organic carbon concentrations, Atmos. Environ., 33, 2771-2781, 1999.

10 Chakraborty, A. and Gupta, T.: Chemical Characterization and Source Apportionment of Submicron $\left(\mathrm{PM}_{1}\right)$ Aerosol in Kanpur Region, Aerosol Air Qual. Res., 10, 433-445, 2010.

Charlson, R. J., Schwartz, S. E., Hales, J. M., Cess, R. D., Coakley, J. A., Hansen, J. E., and Hofmann, D. J.: Climate Forcing by Anthropogenic Aerosols, Science, 255, 423-430, doi:10.1126/science.255.5043.423, 1992.

Demoz, B. B., Collett, J. L., and Daube, B. C.: On the Caltech Active Strand Cloudwater Collectors, Atmos. Res., 41, 47-62, 1996.

Duan, F., Liu, X., Yu, T., and Cachier, H.: Identification and estimate of biomass burning contribution to the urban aerosol organic carbon concentrations in Beijing, Atmos. Environ., 38, 1275-1282, 2004.

20 Duvall, R. M., Majestic, B. J., Shafer, M. M., Chuang, P. Y., Simoneit, B. R. T., and Schauer, J. J.: The water-soluble fraction of carbon, sulfur, and crustal elements in Asian aerosols and Asian soils, Atmos. Environ., 42, 5872-5884, 2008.

Eller, P. M. and Cassinelli, M. E.: Elemental carbon (Diesel Exhaust): Method 5040, NIOSH, Cincinnati, OH, USA, 1996.

Ervens, B. and Volkamer, R.: Glyoxal processing by aerosol multiphase chemistry: towards a kinetic modeling framework of secondary organic aerosol formation in aqueous particles, Atmos. Chem. Phys., 10, 8219-8244, doi:10.5194/acp-10-8219-2010, 2010.

Ervens, B., Turpin, B. J., and Weber, R. J.: Secondary organic aerosol formation in cloud droplets and aqueous particles (aqSOA): a review of laboratory, field and model studies,

$30 \quad$ Atmos. Chem. Phys., 11, 11069-11102, doi:10.5194/acp-11-11069-2011, 2011.

Fuzzi, S., Decesari, S., Facchini, M. C., Matta, E., Mircea, M., and Tagliavini, E.: A simplified model of the water soluble organic component of atmospheric aerosols, Geophys. Res. Lett., 28, 4079-4082, doi:10.1029/2001gl013418, 2001.

\section{ACPD}

$12,14483-14524,2012$

\section{Relationship \\ between organic and \\ inorganic content of \\ the aerosol}

D. S. Kaul et al.

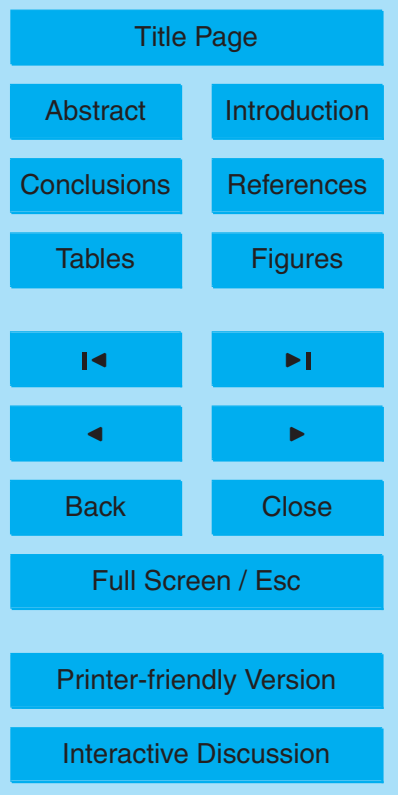


Galloway, M. M., Chhabra, P. S., Chan, A. W. H., Surratt, J. D., Flagan, R. C., Seinfeld, J. H., and Keutsch, F. N.: Glyoxal uptake on ammonium sulphate seed aerosol: reaction products and reversibility of uptake under dark and irradiated conditions, Atmos. Chem. Phys., 9, 33313345, doi:10.5194/acp-9-3331-2009, 2009.

5 Gao, S., Ng, N. L., Keywood, M., Varutbangkul, V., Bahreini, R., Nenes, A., He, J., Yoo, K. Y., Beauchamp, J. L., Hodyss, R. P., Flagan, R. C., and Seinfeld, J. H.: Particle Phase Acidity and Oligomer Formation in Secondary Organic Aerosol, Environ. Sci. Tech., 38, 6582-6589, doi:10.1021/es049125k, 2004.

Gupta, T., Chakraborty, A., and Ujinwal, K. K.: Development and Performance Evaluation of an Indigenously Developed Air Sampler Designed to Collect Submicron Aerosol, Annals of Indian National Academy of Engineering (INAE), 7, 189-193, 2010.

Gupta, T., Jaiprakash, and Dubey, S.: Field performance evaluation of a newly developed $\mathrm{PM}_{2.5}$ sampler at IIT Kanpur, Sci. Total Environ., 409, 3500-3507, 2011.

Haidouti, C., Chronopoulou, A., and Chronopoulos, J.: Effects of fluoride emissions from industry on the fluoride concentration of soils and vegetation, Biochem. Syst. Ecol., 21, 195-208, 1993.

Herckes, P., Leenheer, J. A., and Collett, J. L.: Comprehensive Characterization of Atmospheric Organic Matter in Fresno, California Fog Water, Environ. Sci. Tech., 41, 393-399, doi:10.1021/es0607988, 2006.

20 Herckes, P., Chang, H., Lee, T., and Collett, J.: Air Pollution Processing by Radiation Fogs, Water Air Soil Poll., 181, 65-75, doi:10.1007/s11270-006-9276-x, 2007.

Hering, S. V. and Friedlander, S. K.: Origins of aerosol sulfur size distributions in the Los Angeles basin, Atmos. Environ., 16, 2647-2656, 1982.

Herrmann, H., Tilgner, A., Barzaghi, P., Majdik, Z., Gligorovski, S., Poulain, L., and Monod, A.: Towards a more detailed description of tropospheric aqueous phase organic chemistry: CAPRAM 3.0, Atmos. Environ., 39, 4351-4363, 2005.

Hou, B., Zhuang, G., Zhang, R., Liu, T., Guo, Z., and Chen, Y.: The implication of carbonaceous aerosol to the formation of haze: Revealed from the characteristics and sources of OC/EC over a mega-city in China, J. Hazard. Mater., 190, 529-536, 2011.

30 Huang, S., Rahn, K. A., and Arimoto, R.: Testing and optimizing two factor-analysis techniques on aerosol at Narragansett, Rhode Island, Atmos. Environ., 33, 2169-2185, 1999.

\section{Relationship between organic and inorganic content of the aerosol}

D. S. Kaul et al.

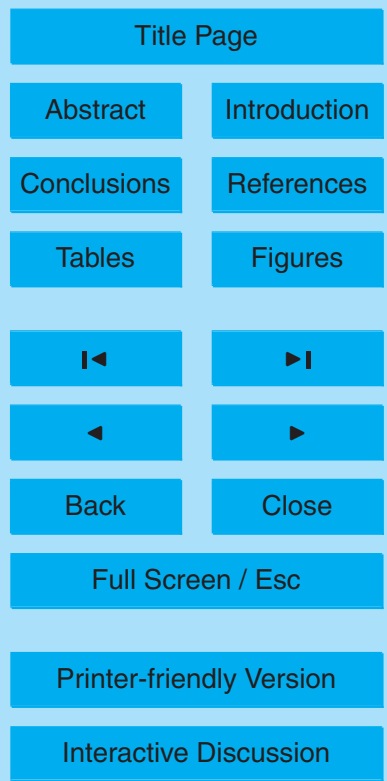


Huang, X. H. H., Ip, H. S. S., and Yu, J. Z.: Secondary organic aerosol formation from ethylene in the urban atmosphere of Hong Kong: A multiphase chemical modeling study, J. Geophys. Res., 116, D03206, doi:10.1029/2010jd014121, 2011.

Jimenez, J. L., Canagaratna, M. R., Donahue, N. M., Prevot, A. S. H., Zhang, Q., Kroll, J. H., 5 DeCarlo, P. F., Allan, J. D., Coe, H., Ng, N. L., Aiken, A. C., Docherty, K. S., Ulbrich, I. M., Grieshop, A. P., Robinson, A. L., Duplissy, J., Smith, J. D., Wilson, K. R., Lanz, V. A., Hueglin, C., Sun, Y. L., Tian, J., Laaksonen, A., Raatikainen, T., Rautiainen, J., Vaattovaara, P., Ehn, M., Kulmala, M., Tomlinson, J. M., Collins, D. R., Cubison, M. J., E, Dunlea, J., Huffman, J. A., Onasch, T. B., Alfarra, M. R., Williams, P. I., Bower, K., Kondo, Y., Schneider, J., Drewnick, F., Borrmann, S., Weimer, S., Demerjian, K., Salcedo, D., Cottrell, L., Griffin, R., Takami, A., Miyoshi, T., Hatakeyama, S., Shimono, A., Sun, J. Y., Zhang, Y. M., Dzepina, K., Kimmel, J. R., Sueper, D., Jayne, J. T., Herndon, S. C., Trimborn, A. M., Williams, L. R., Wood, E. C., Middlebrook, A. M., Kolb, C. E., Baltensperger, U., and Worsnop, D. R.: Evolution of Organic Aerosols in the Atmosphere, Science, 326, 1525-1529, doi:10.1126/science.1180353, 152009.

John, W., Wall, S. M., Ondo, J. L., and Winklmayr, W.: Modes in the size distributions of atmospheric inorganic aerosol, Atmos. Environ. A-Gen., 24, 2349-2359, 1990.

Jung, J., Kim, Y. J., Aggarwal, S. G., and Kawamura, K.: Hygroscopic property of water-soluble organic-enriched aerosols in Ulaanbaatar, Mongolia during the cold winter of 2007, Atmos.

20 Environ., 45, 2722-2729, 2011.

Kanakidou, M., Seinfeld, J. H., Pandis, S. N., Barnes, I., Dentener, F. J., Facchini, M. C., Van Dingenen, R., Ervens, B., Nenes, A., Nielsen, C. J., Swietlicki, E., Putaud, J. P., Balkanski, Y., Fuzzi, S., Horth, J., Moortgat, G. K., Winterhalter, R., Myhre, C. E. L., Tsigaridis, K., Vignati, E., Stephanou, E. G., and Wilson, J.: Organic aerosol and global climate modelling: a review, Atmos. Chem. Phys., 5, 1053-1123, doi:10.5194/acp-5-1053-2005, 2005.

Kaul, D. S., Gupta, T., Tripathi, S. N., Tare, V., and Collett Jr., J. L.: Secondary Organic Aerosol: A comparison between foggy and non-foggy days, Environ. Sci. Tech., 45, 7307-7313, 2011.

Kerminen, V.-M. and Wexler, A. S.: Growth laws for atmospheric aerosol particles: An examination of the bimodality of the accumulation mode, Atmos. Environ., 29, 3263-3275, 1995.

30 Krämer, M., Beltz, N., Schell, D., Schütz, L., Sprengard-Eichel, C., and Wurzler, S.: Cloud processing of continental aerosol particles: Experimental investigations for different drop sizes, J. Geophys. Res., 105, 11739-11752, doi:10.1029/1999jd901061, 2000.

\section{ACPD}

$12,14483-14524,2012$

\section{Relationship \\ between organic and \\ inorganic content of the aerosol}

D. S. Kaul et al.

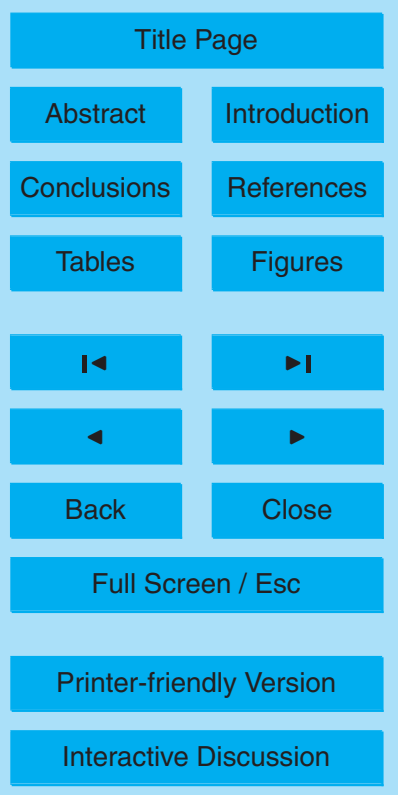


Kua, J., Krizner, H. E., and De Haan, D. O.: Thermodynamics and Kinetics of Imidazole Formation from Glyoxal, Methylamine, and Formaldehyde: A Computational Study, J. Phys. Chem. A, 115, 1667-1675, doi:10.1021/jp111527x, 2011.

Lee, Y. L. and Sequeira, R.: Water-soluble aerosol and visibility degradation in Hong Kong during autumn and early winter, 1998, Environ. Pollut., 116, 225-233, 2002.

Lillis, D., Cruz, C. N., Collett, J., Willard Richards, L., and Pandis, S. N.: Production and removal of aerosol in a polluted fog layer: model evaluation and fog effect on PM, Atmos. Environ., 33, 4797-4816, 1999.

Maria, S. F., Russell, L. M., Gilles, M. K., and Myneni, S. C. B.: Organic Aerosol Growth Mechanisms and Their Climate-Forcing Implications, Science, 306, 1921-1924, doi:10.1126/science.1103491, 2004.

Mehta, B., Venkataraman, C., Bhushan, M., and Tripathi, S. N.: Identification of sources affecting fog formation using receptor modeling approaches and inventory estimates of sectoral emissions, Atmos. Environ., 43, 1288-1295, 2009.

Meng, Z., Seinfeld, J. H., Saxena, P., and Kim, Y. P.: Contribution of Water to Particulate Mass in the South Coast Air Basin, Aerosol Sci. Tech., 22, 111-123, doi:10.1080/02786829408959731, 1995.

Moore, K. F., Eli Sherman, D., Reilly, J. E., Hannigan, M. P., Lee, T., and Collett Jr., J. L.: Drop size-dependent chemical composition of clouds and fogs. Part II: Relevance to interpreting 20 the aerosol/trace gas/fog system, Atmos. Environ., 38, 1403-1415, 2004.

Ng, N. L., Canagaratna, M. R., Zhang, Q., Jimenez, J. L., Tian, J., Ulbrich, I. M., Kroll, J. H., Docherty, K. S., Chhabra, P. S., Bahreini, R., Murphy, S. M., Seinfeld, J. H., Hildebrandt, L., Donahue, N. M., DeCarlo, P. F., Lanz, V. A., Prévôt, A. S. H., Dinar, E., Rudich, Y., and Worsnop, D. R.: Organic aerosol components observed in Northern Hemispheric datasets from Aerosol Mass Spectrometry, Atmos. Chem. Phys., 10, 4625-4641, doi:10.5194/acp-104625-2010, 2010.

Noziere, B., Dziedzic, P., and Cordova, A.: Products and Kinetics of the Liquid-Phase Reaction of Glyoxal Catalyzed by Ammonium Ions $\left(\mathrm{NH}_{4}^{+}\right)$, J. Phys. Chem. A, 113, 231-237, doi:10.1021/jp8078293, 2008.

so Odum, J. R., Jungkamp, T. P. W., Griffin, R. J., Flagan, R. C., and Seinfeld, J. H.: The Atmospheric Aerosol-Forming Potential of Whole Gasoline Vapor, Science, 276, 96-99, doi:10.1126/science.276.5309.96, 1997.

\section{Relationship \\ between organic and inorganic content of the aerosol}

D. S. Kaul et al.

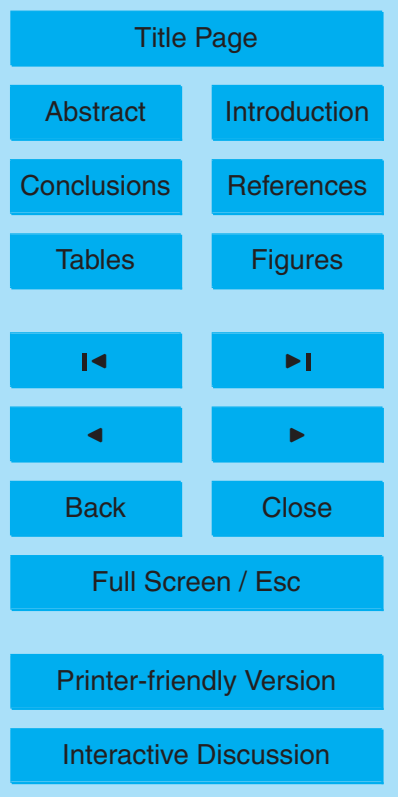


Offenberg, J. H., Lewandowski, M., Edney, E. O., Kleindienst, T. E., and Jaoui, M.: Influence of Aerosol Acidity on the Formation of Secondary Organic Aerosol from Biogenic Precursor Hydrocarbons, Environ. Sci. Tech., 43, 7742-7747, doi:10.1021/es901538e, 2009.

Orrling, D., Fitzgerald, E., Ivanov, A., and Molina, M.: Enhanced sulfate formation on ozoneexposed soot, J. Aerosol Sci., 42, 615-620, 2011.

Paatero, P.: Least squares formulation of robust non-negative factor analysis, Chemometr. Intell. Lab., 37, 23-35, 1997.

Paatero, P.: The Multilinear Engine: A Table-Driven, Least Squares Program for Solving Multilinear Problems, including the n-Way Parallel Factor Analysis Model, J. Comput. Graph. Stat., 10 8, 854-888, 1999.

Paatero, P. and Hopke, P. K.: Discarding or downweighting high-noise variables in factor analytic models, Anal. Chim. Acta, 490, 277-289, 2003.

Paatero, P. and Tapper, U.: Positive matrix factorization: A non-negative factor model with optimal utilization of error estimates of data values, Environmetrics, 5, 111-126, doi:10.1002/env.3170050203, 1994.

Pathak, R. K., Louie, P. K. K., and Chan, C. K.: Characteristics of aerosol acidity in Hong Kong, Atmos. Environ., 38, 2965-2974, 2004.

Perri, M. J., Lim, Y. B., Seitzinger, S. P., and Turpin, B. J.: Organosulfates from glycolaldehyde in aqueous aerosols and clouds: Laboratory studies, Atmos. Environ., 44, 2658-2664, 2010.

Pickle, T., Allen, D. T., and Pratsinis, S. E.: The sources and size distributions of aliphatic and carbonyl carbon in Los Angeles aerosol, Atmos. Environ. A-Gen., 24, 2221-2228, 1990.

Polissar, A. V., Paatero, P., Hopke, P. K., Malm, W. C., and Sisler, J. F.: Atmospheric aerosol over Alaska 2. Elemental composition and sources, J. Geophys. Res., 103, 19045-19057, doi:10.1029/98jd01212, 1998.

Pope, C. A., Burnett, R. T., Thun, M. J., Calle, E. E., Krewski, D., Ito, K., and Thurston, G. D.: Lung Cancer, Cardiopulmonary Mortality, and Long-term Exposure to Fine Particulate Air Pollution, JAMA, J. Amer. Med. Assoc., 287, 1132-1141, doi:10.1001/jama.287.9.1132, 2002.

Pratt, K. A., Murphy, S. M., Subramanian, R., DeMott, P. J., Kok, G. L., Campos, T., Rogers, D. C., Prenni, A. J., Heymsfield, A. J., Seinfeld, J. H., and Prather, K. A.: Flight-based chemical characterization of biomass burning aerosols within two prescribed burn smoke plumes, Atmos. Chem. Phys., 11, 12549-12565, doi:10.5194/acp-11-12549-2011, 2011.
ACPD

12, 14483-14524, 2012

Relationship

between organic and

inorganic content of the aerosol

D. S. Kaul et al.

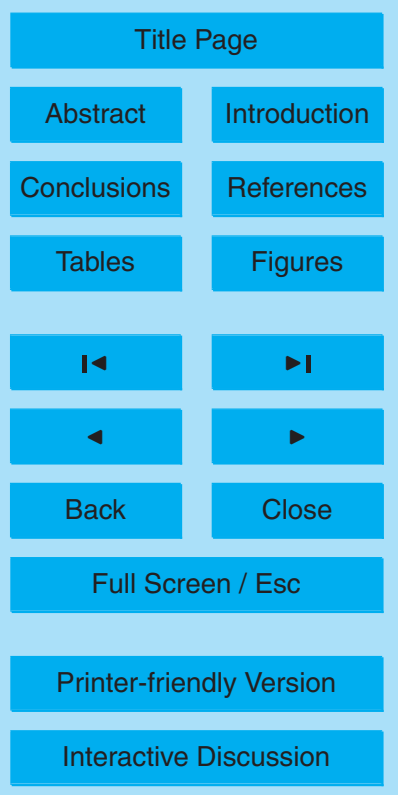


Raja, S., Raghunathan, R., Yu, X.-Y., Lee, T., Chen, J., Kommalapati, R. R., Murugesan, K., Shen, X., Qingzhong, Y., Valsaraj, K. T., and Collett Jr., J. L.: Fog chemistry in the TexasLouisiana Gulf Coast corridor, Atmos. Environ., 42, 2048-2061, 2008.

Ravishankara, A. R.: Heterogeneous and Multiphase Chemistry in the Troposphere, Science, 276, 1058-1065, doi:10.1126/science.276.5315.1058, 1997.

Reff, A., Eberly, S. I., and Bhave, P. V.: Receptor modeling of ambient particulate matter data using positive matrix factorization: review of existing methods, J. Air Waste Manage. Assoc., 57, 146-154, 2007.

Rengarajan, R., Sudheer, A. K., and Sarin, M. M.: Aerosol acidity and secondary organic aerosol formation during wintertime over urban environment in western India, Atmos. Environ., 45, 1940-1945, 2011.

Riemer, N., West, M., Zaveri, R., and Easter, R.: Estimating black carbon aging time-scales with a particle-resolved aerosol model, J. Aerosol Sci., 41, 143-158, 2010.

Romero, F. and Oehme, M.: Organosulfates - A New Component of Humic-Like Substances 15 in Atmospheric Aerosols?, J. Atmos. Chem., 52, 283-294, doi:10.1007/s10874-005-0594-y, 2005.

Shapiro, E. L., Szprengiel, J., Sareen, N., Jen, C. N., Giordano, M. R., and McNeill, V. F.: Lightabsorbing secondary organic material formed by glyoxal in aqueous aerosol mimics, Atmos. Chem. Phys., 9, 2289-2300, doi:10.5194/acp-9-2289-2009, 2009.

20 Sievering, H., Boatman, J., Gorman, E., Kim, Y., Anderson, L., Ennis, G., Luria, M., and Pandis, S.: Removal of sulphur from the marine boundary layer by ozone oxidation in sea-salt aerosols, Nature, 360, 571-573, 1992.

Spracklen, D. V., Jimenez, J. L., Carslaw, K. S., Worsnop, D. R., Evans, M. J., Mann, G. W., Zhang, Q., Canagaratna, M. R., Allan, J., Coe, H., McFiggans, G., Rap, A., and Forster, P.: Aerosol mass spectrometer constraint on the global secondary organic aerosol budget, Atmos. Chem. Phys., 11, 12109-12136, doi:10.5194/acp-11-12109-2011, 2011.

Stone, E. A., Hedman, C. J., Sheesley, R. J., Shafer, M. M., and Schauer, J. J.: Investigating the chemical nature of humic-like substances (HULIS) in North American atmospheric aerosols by liquid chromatography tandem mass spectrometry, Atmos. Environ., 43, 42054213, 2009.

Stone, E. A., Yang, L., Yu, L. E., and Rupakheti, M.: Characterization of organosulfates in atmospheric aerosols at Four Asian locations, Atmos. Environ., 47, 323-329, 2012.

\section{ACPD}

$12,14483-14524,2012$

\section{Relationship \\ between organic and \\ inorganic content of the aerosol}

D. S. Kaul et al.

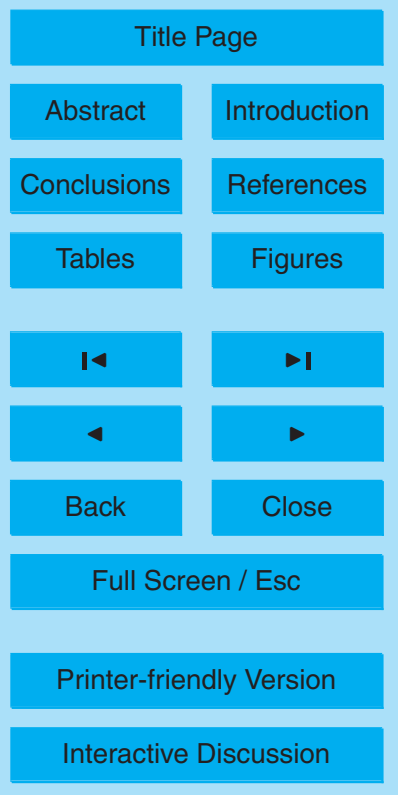


Sun, Y., Zhuang, G., Tang, A., Wang, Y., and An, Z.: Chemical Characteristics of $\mathrm{PM}_{2.5}$ and $\mathrm{PM}_{10}$ in Haze-Fog Episodes in Beijing, Environ. Sci. Tech., 40, 3148-3155, doi:10.1021/es051533g, 2006.

Sunyer, J.: Urban air pollution and chronic obstructive pulmonary disease: a review, Eur. Respir. $5 \quad$ J., 17, 1024-1033, 2001.

Surratt, J. D., Kroll, J. H., Kleindienst, T. E., Edney, E. O., Claeys, M., Sorooshian, A., Ng, N. L., Offenberg, J. H., Lewandowski, M., Jaoui, M., Flagan, R. C., and Seinfeld, J. H.: Evidence for Organosulfates in Secondary Organic Aerosol, Environ. Sci. Tech., 41, 517-527, doi:10.1021/es062081q, 2006.

10 Tanner, R. L., Olszyna, K. J., Edgerton, E. S., Knipping, E., and Shaw, S. L.: Searching for evidence of acid-catalyzed enhancement of secondary organic aerosol formation using ambient aerosol data, Atmos. Environ., 43, 3440-3444, 2009.

Trainic, M., Abo Riziq, A., Lavi, A., Flores, J. M., and Rudich, Y.: The optical, physical and chemical properties of the products of glyoxal uptake on ammonium sulfate seed aerosols, Atmos. Chem. Phys., 11, 9697-9707, doi:10.5194/acp-11-9697-2011, 2011.

Turpin, B. J. and Huntzicker, J. J.: Identification of secondary organic aerosol episodes and quantitation of primary and secondary organic aerosol concentrations during SCAQS, Atmos. Environ., 29, 3527-3544, 1995.

Ulevicius, V., Trakumas, S., and Girgzdys, A.: Aerosol size distribution transformation in fog, 20 Atmos. Environ., 28, 795-800, 1994.

Volkamer, R., San Martini, F., Molina, L. T., Salcedo, D., Jimenez, J. L., and Molina, M. J.: A missing sink for gas-phase glyoxal in Mexico City: Formation of secondary organic aerosol, Geophys. Res. Lett., 34, L19807, doi:10.1029/2007gl030752, 2007.

Wang, J., Jacob, D. J., and Martin, S. T.: Sensitivity of sulfate direct climate forcing to the hysteresis of particle phase transitions, J. Geophys. Res., 113, D11207, doi:10.1029/2007jd009368, 2008.

Wang, L., Xu, W., Khalizov, A. F., Zheng, J., Qiu, C., and Zhang, R.: Laboratory Investigation on the Role of Organics in Atmospheric Nanoparticle Growth, J. Phys. Chem. A, 115, 89408947, doi:10.1021/jp1121855, 2011a.

30 Wang, Y., Zhuang, G., Tang, A., Yuan, H., Sun, Y., Chen, S., and Zheng, A.: The ion chemistry and the source of $\mathrm{PM}_{2.5}$ aerosol in Beijing, Atmos. Environ., 39, 3771-3784, 2005.

\section{ACPD}

12, 14483-14524, 2012

\section{Relationship between organic and inorganic content of the aerosol}

D. S. Kaul et al.

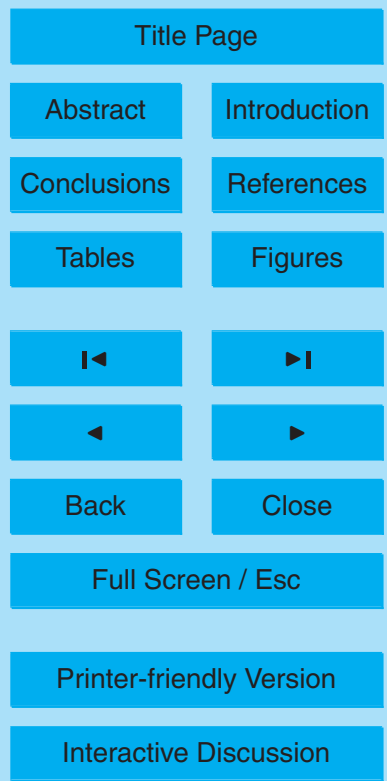


Wang, Y., Guo, J., Wang, T., Ding, A., Gao, J., Zhou, Y., Collett Jr., J. L., and Wang, W.: Influence of regional pollution and sandstorms on the chemical composition of cloud/fog at the summit of Mt. Taishan in northern China, Atmos. Res., 99, 434-442, 2011b.

Wang, Z., Wang, T., Guo, J., Gao, R., Xue, L., Zhang, J., Zhou, Y., Zhou, X., Zhang, Q., and Wang, W.: Formation of secondary organic carbon and cloud impact on carbonaceous aerosols at Mount Tai, North China, Atmos. Environ., 46, 516-527, 2012.

Xiao, R., Takegawa, N., Kondo, Y., Miyazaki, Y., Miyakawa, T., Hu, M., Shao, M., Zeng, L. M., Hofzumahaus, A., Holland, F., Lu, K., Sugimoto, N., Zhao, Y., and Zhang, Y. H.: Formation of submicron sulfate and organic aerosols in the outflow from the urban region of the Pearl

10 River Delta in China, Atmos. Environ., 43, 3754-3763, 2009.

Zhang, Q. and Tie, X.: High solubility of $\mathrm{SO}_{2}$ : evidence in an intensive fog event measured in the NCP region, China, Atmos. Chem. Phys. Discuss., 11, 2931-2947, doi:10.5194/acpd11-2931-2011, 2011.

Zhang, Q., Jimenez, J. L., Canagaratna, M. R., Allan, J. D., Coe, H., Ulbrich, I., Alfarra, M. R., 15 Takami, A., Middlebrook, A. M., Sun, Y. L., Dzepina, K., Dunlea, E., Docherty, K., DeCarlo, P. F., Salcedo, D., Onasch, T., Jayne, J. T., Miyoshi, T., Shimono, A., Hatakeyama, S., Takegawa, N., Kondo, Y., Schneider, J., Drewnick, F., Borrmann, S., Weimer, S., Demerjian, K., Williams, P., Bower, K., Bahreini, R., Cottrell, L., Griffin, R. J., Rautiainen, J., Sun, J. Y., Zhang, Y. M., and Worsnop, D. R.: Ubiquity and dominance of oxygenated species in organic aerosols in anthropogenically-influenced Northern Hemisphere midlatitudes, Geophys. Res. Lett., 34, L13801, doi:10.1029/2007gl029979, 2007.

Zhang, X., Hecobian, A., Zheng, M., Frank, N. H., and Weber, R. J.: Biomass burning impact on $\mathrm{PM}_{2.5}$ over the southeastern US during 2007: integrating chemically speciated FRM filter measurements, MODIS fire counts and PMF analysis, Atmos. Chem. Phys., 10, 6839-6853, doi:10.5194/acp-10-6839-2010, 2010.

\section{ACPD}

$12,14483-14524,2012$

\section{Relationship \\ between organic and \\ inorganic content of the aerosol}

D. S. Kaul et al.

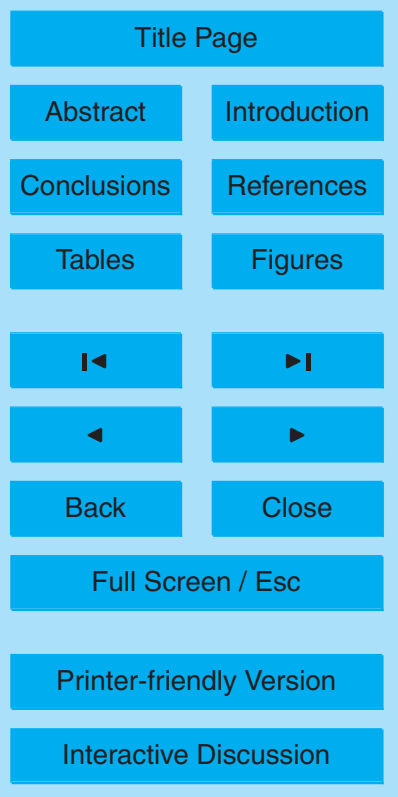




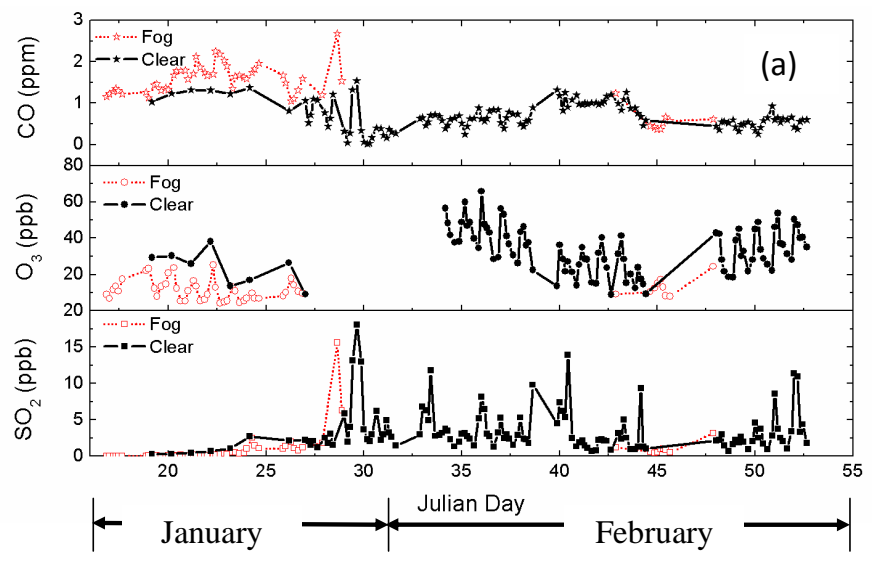

\section{ACPD}

12, 14483-14524, 2012

\section{Relationship between organic and inorganic content of the aerosol}

D. S. Kaul et al.

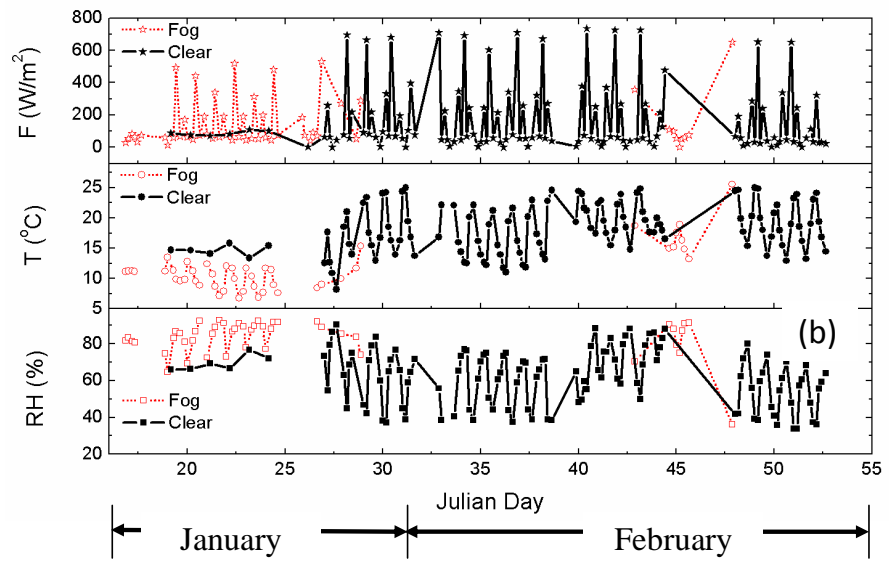

Title Page

Abstract

Introduction

Conclusions

References

Tables

Figures

14

-1

4

Back

Close

\section{Full Screen / Esc}

Fig. 1. (a) The time series of trace gas $\left(\mathrm{CO}, \mathrm{O}_{3}, \mathrm{SO}_{2}\right)$ concentration and (b) solar flux $(F), 5$ atmospheric temperature $(T)$ and relative humidity $(\mathrm{RH})$ during foggy and nonfoggy (clear) 6 episodes.

Printer-friendly Version

Interactive Discussion

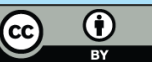



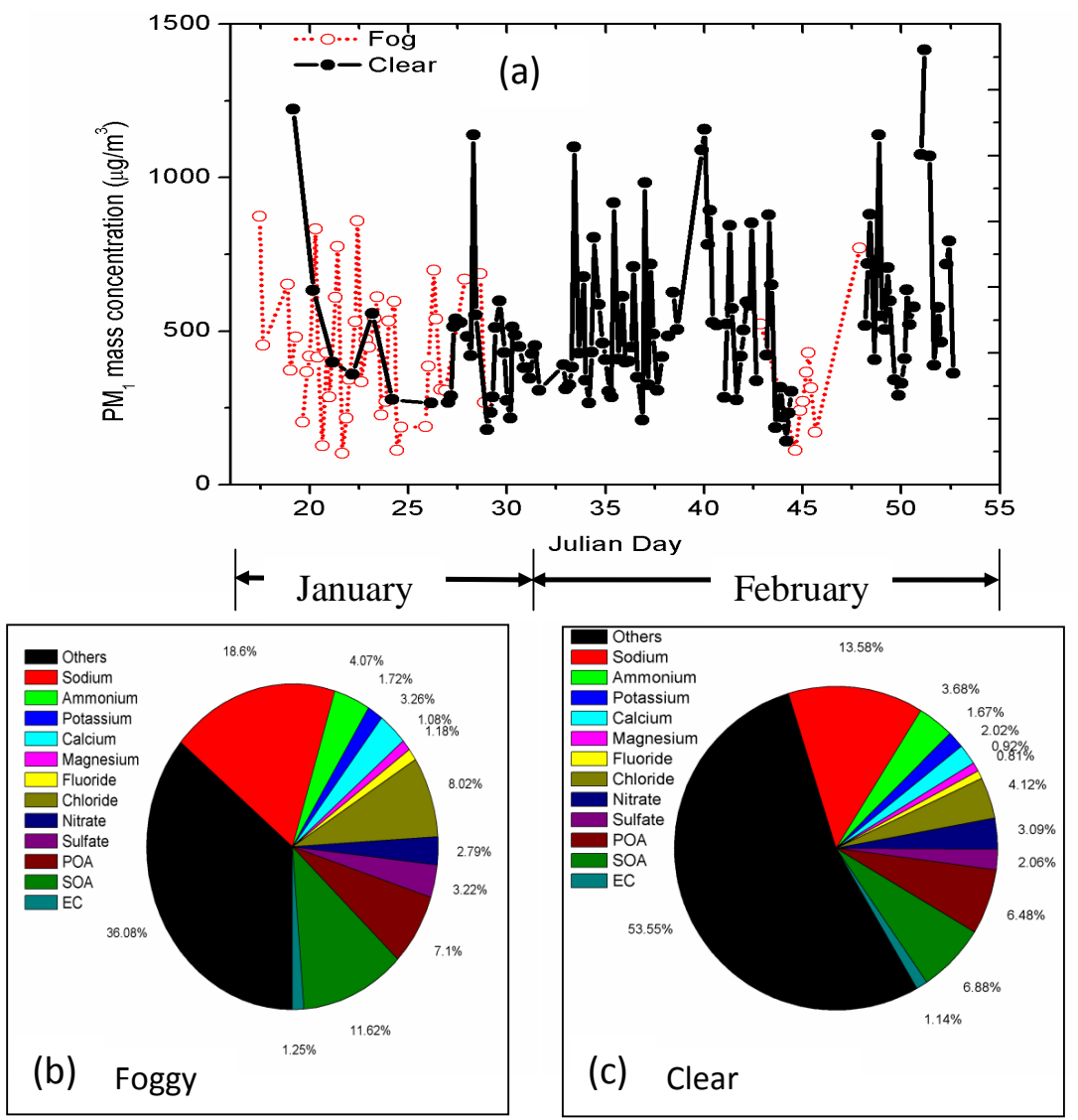

\section{ACPD}

$12,14483-14524,2012$

\section{Relationship between organic and inorganic content of the aerosol}

D. S. Kaul et al.

\section{Title Page}

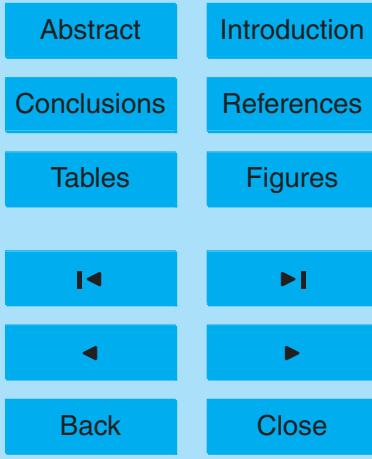

Full Screen / Esc

Fig. 2. (a) $P M_{1}$ mass concentration during foggy and nonfoggy (clear) episodes (b) aerosol 4 chemical composition during foggy episode (c) aerosol chemical composition during nonfoggy 5 (clear) episode. POA, SOA and EC stands for primary organic aerosols, secondary organic 6 aerosols and elemental carbon, respectively. 


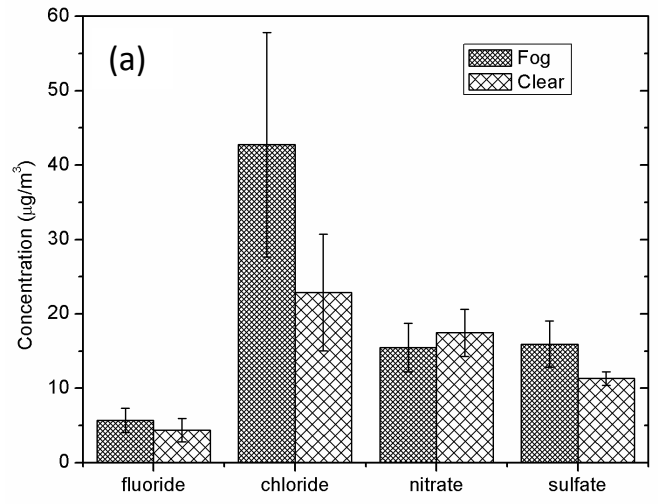

\section{ACPD}

12, 14483-14524, 2012

\section{Relationship between organic and inorganic content of the aerosol}

D. S. Kaul et al.
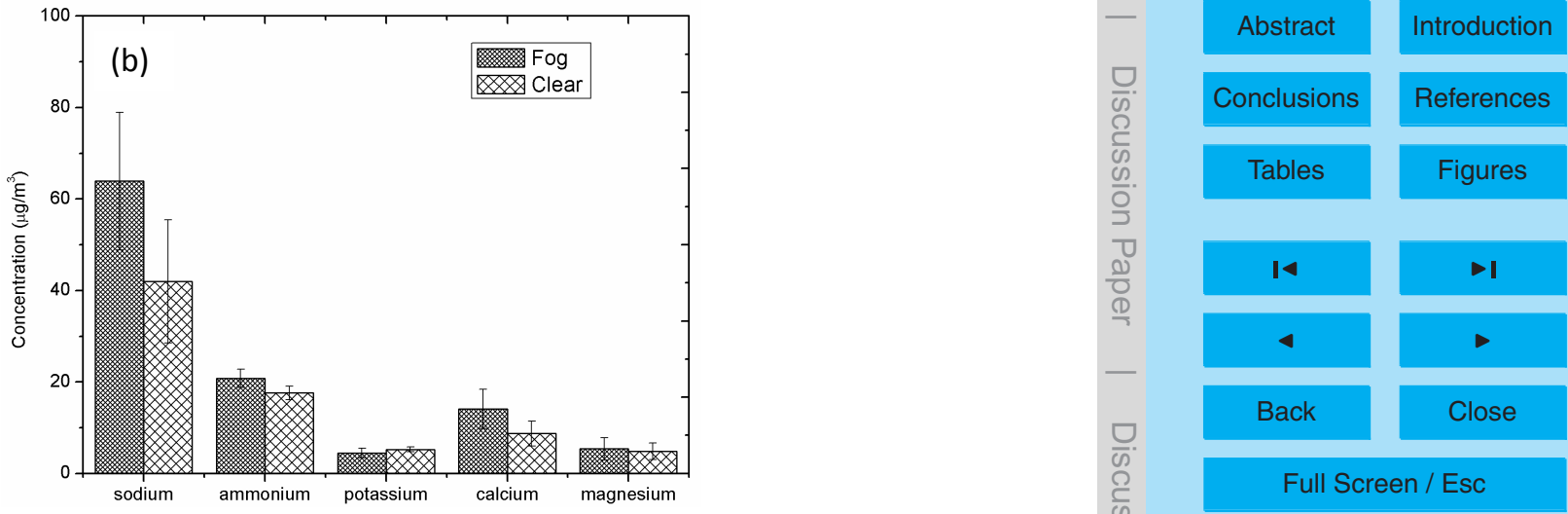

Full Screen / Esc

Fig. 3. (a) The study average anion concentrations and (b) cation concentrations in $\mathrm{PM}_{1}$ during 4 foggy and nonfoggy (clear) episode.

Printer-friendly Version

Interactive Discussion 


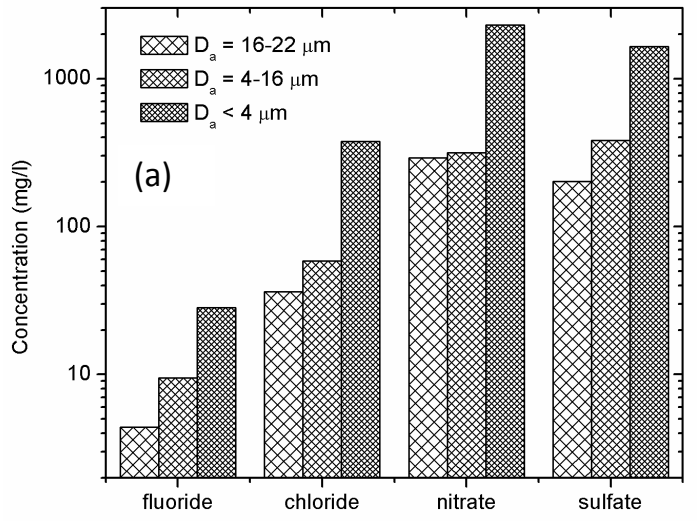

\section{ACPD}

12, 14483-14524, 2012

\section{Relationship between organic and inorganic content of the aerosol}

D. S. Kaul et al.

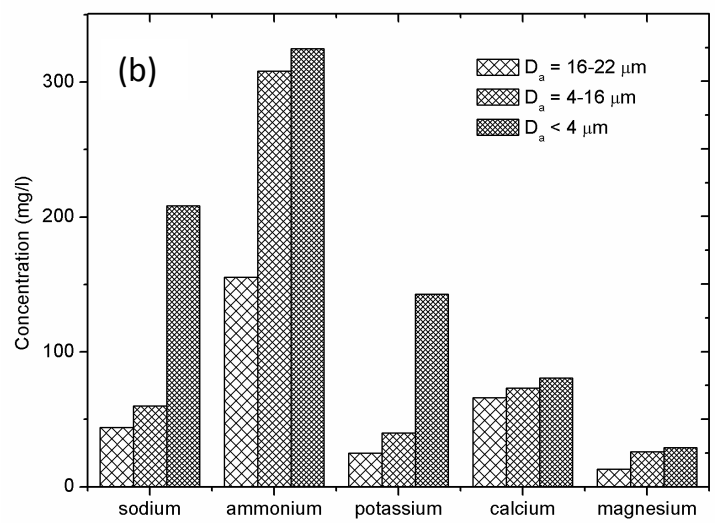

\section{Abstract}

Conclusions

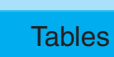

14

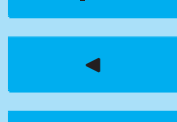

Back
Title Page

\section{Full Screen / Esc}

Printer-friendly Version

Interactive Discussion 3 aerodynamic diameter $\left(D_{a}\right) 4,16$ and $22 \mu \mathrm{m}$. Due to large standard deviation, average 4 concentration data $( \pm 1 \sigma)$ is included in Table S6 (a). 


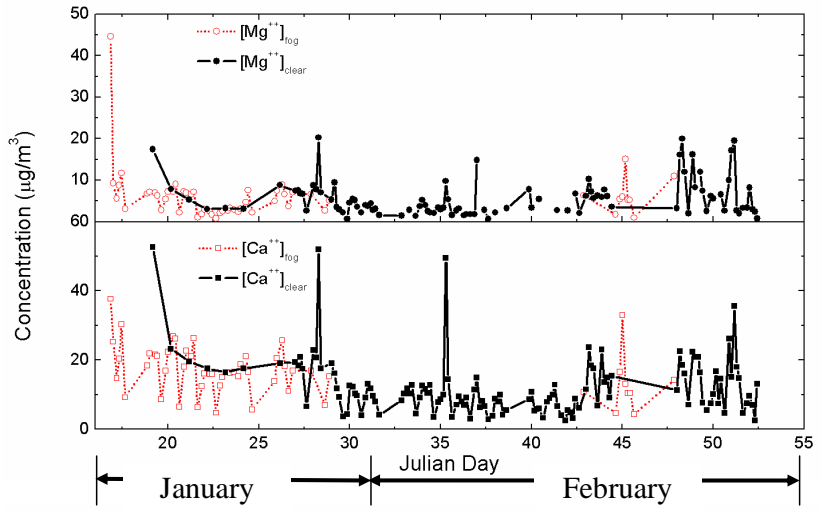

\section{ACPD}

$12,14483-14524,2012$

\section{Relationship between organic and inorganic content of the aerosol}

D. S. Kaul et al.

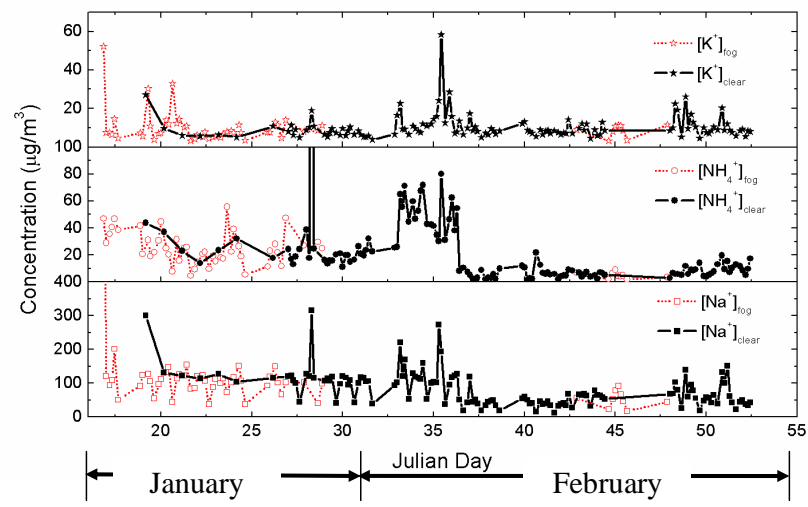

Title Page

Abstract

Introduction

Conclusions

References

Tables

Figures

14

I

4

Back

Close

Full Screen / Esc

Fig. 5. Cation concentration during foggy and nonfoggy (clear) episodes.

Printer-friendly Version

Interactive Discussion 


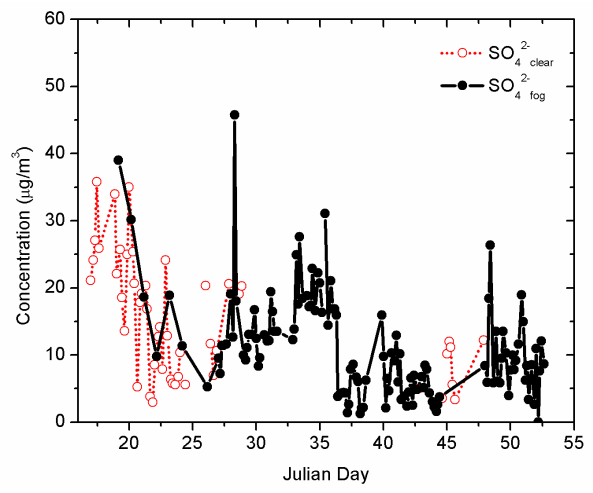

\section{ACPD}

12, 14483-14524, 2012

\section{Relationship between organic and inorganic content of the aerosol}

D. S. Kaul et al.

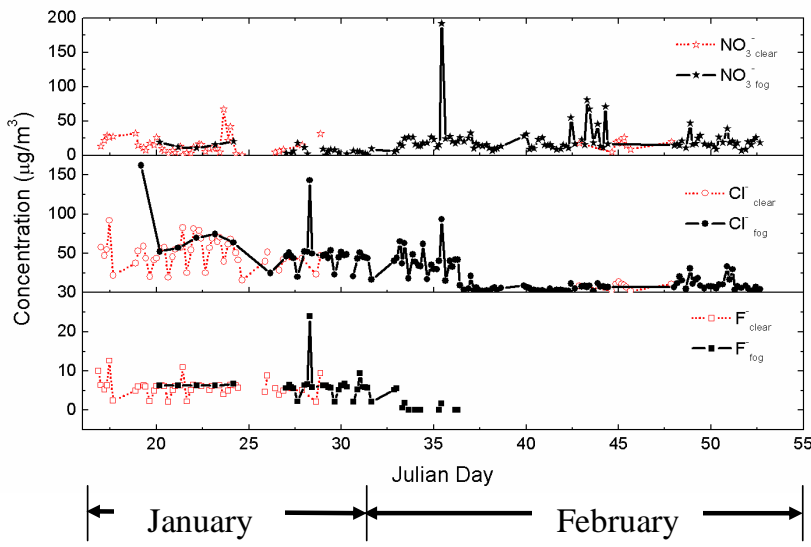

Title Page

Abstract

Introduction

Conclusions

References

Tables

Figures

14

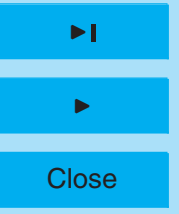

Back

Full Screen / Esc

Fig. 6. Anion concentration during foggy and nonfoggy (clear) episodes.

Printer-friendly Version

Interactive Discussion 


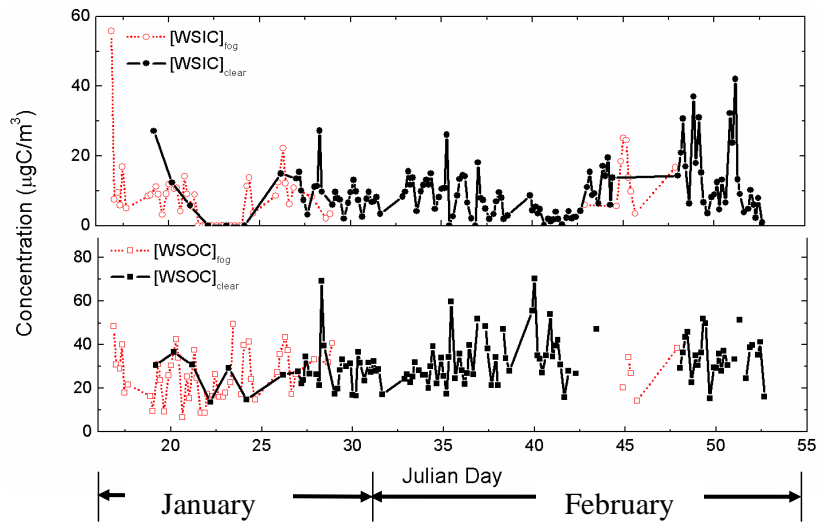

\section{ACPD}

$12,14483-14524,2012$

\section{Relationship between organic and inorganic content of the aerosol}

D. S. Kaul et al.

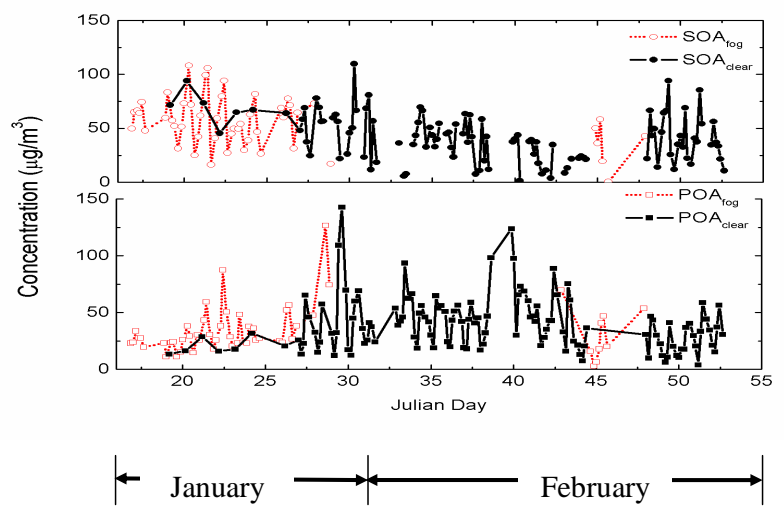

Title Page

Abstract

Introduction

Conclusions

References

Tables

Figures

14

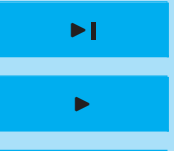

Back

Close

Full Screen / Esc

Fig. 7. The water soluble inorganic carbon (WSIC), water soluble organic carbon (WSOC), 6 secondary organic aerosol (SOA) and primary organic aerosol (POA) during foggy and nonfoggy 7 (clear) episodes, the procedure to derive POA and SOA are documented in Kaul et al. (2011).

Printer-friendly Version

Interactive Discussion

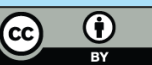


(a)

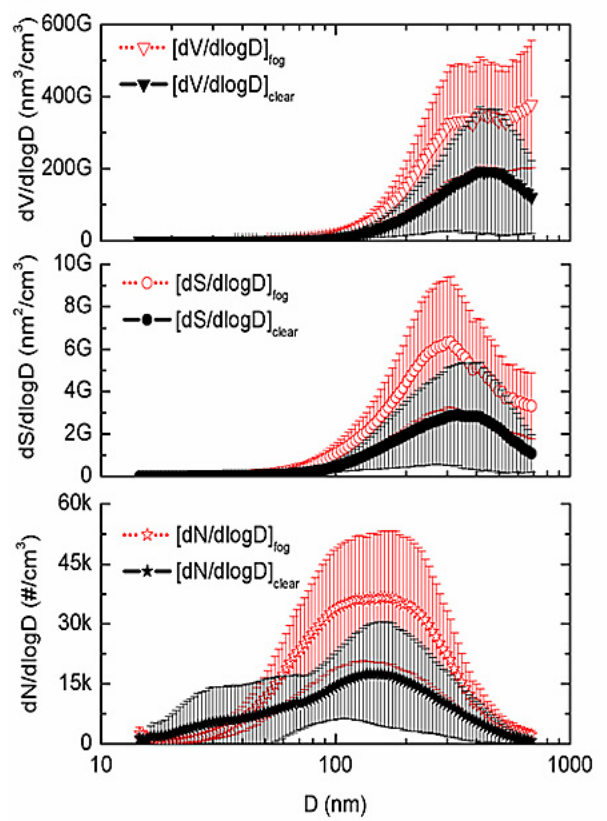

(b)
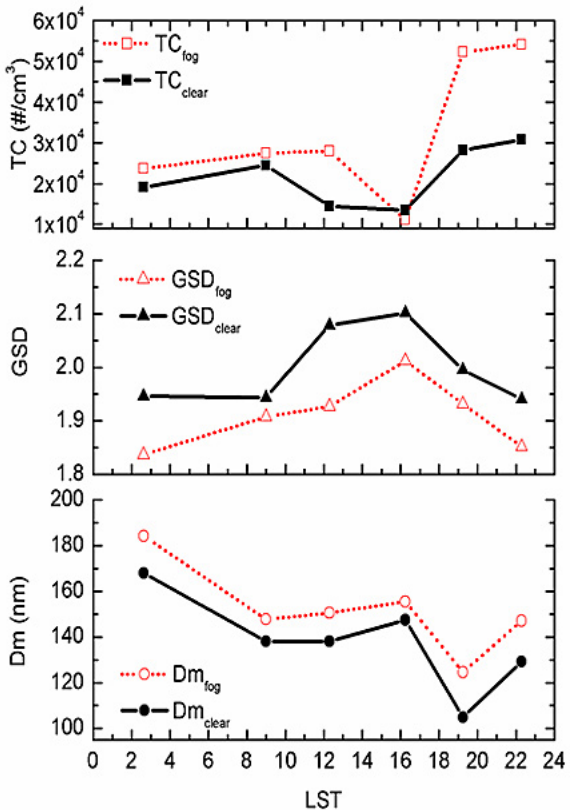

Fig. 8. (a) The average number $(N)$, surface $(S)$ and volume $(V)$ size distribution of aerosol 2 during foggy and nonfoggy (clear) episode at a representative sampling duration (11:00 a.m.01:30 p.m.) which is dominated by secondary organic aerosol formation during both foggy and 4 nonfoggy episode. $D$ is aerosol mobility diameter. (b) The average diurnal variations of modal 5 diameter of the number size duration (Dm), geometric standard deviation (GSD) and total 6 number concentration (TC) during foggy and nonfoggy (clear) episodes. LST stands for local standard time. Due to overlapping standard deviations, average TC, Dm and GSD data $( \pm 1 \sigma)$ is 8 included in Table S6 (b).

\section{ACPD}

$12,14483-14524,2012$

\section{Relationship between organic and inorganic content of the aerosol}

D. S. Kaul et al.

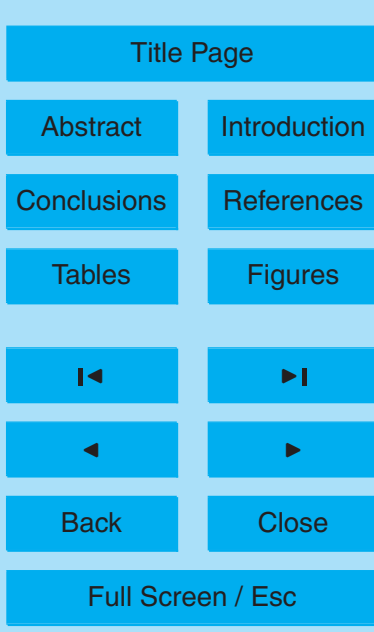

Printer-friendly Version

Interactive Discussion 


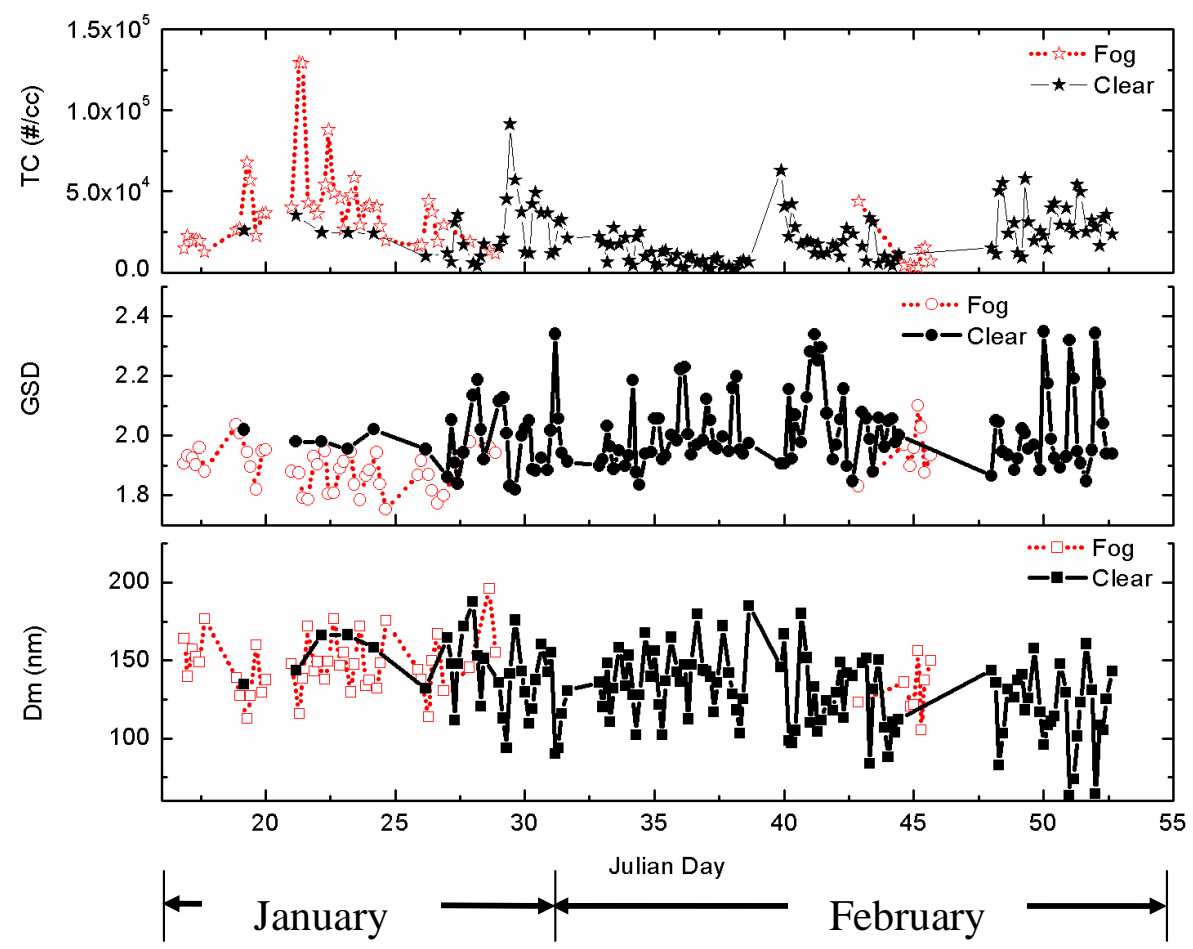

Fig. 9. The total number concentration (TC), geometric standard deviation (GSD) and modal 4 diameter of the number size distribution $(\mathrm{Dm})$ during foggy and nonfoggy (clear) episodes.

\section{ACPD}

$12,14483-14524,2012$

\section{Relationship between organic and inorganic content of the aerosol \\ D. S. Kaul et al.}

\section{Title Page}

\section{Abstract}

Introduction

Conclusions

References

Tables

Figures

14

I

4

Back

Close

Full Screen / Esc

Printer-friendly Version

Interactive Discussion 